BNWL-2104

UC-70

\title{
A Brief Assessment of Some Technical and Radiological Hazard Factors Affecting Clad Waste Management
}

by

G. E. Zima

July 30, 1976

Prepared for the Energy Research and Development Administration under Contract E(45-1)-1830

\section{Battelle}




\section{NOTICE}

This report was prepared as an account of work sponsored by the United States Government. Neither the United States nor the Energy Research and Development Administration, nor any of their employees, nor any of their contractors, subcontractors, or their employees, makes any warranty, express or implied, or assumes any legal liability or responsibility for the accuracy, completeness or usefulness of any imformation, apparatus, product or process disclosed, or represents that its use would not infringe privately owned rights.

PACIFIC NORTHWEST LABORATORY

operated by

BATTELLE

for the

ENERGY RESEARCH AND DEVELOPMENT ADMINISTRATION

Under Contract E(45-1)-1830

Printed in the United States of America

Available from

National Technical Information Service

U.S. Department of Commerce

5285 Port Royal Road

Springfield, Virginia 22151

Price: Printed Copy \$5.30; Microfiche \$2.25 


\section{4}

A BRIEF ASSESSMENT OF SOME TECHNICAL AND RADIOLOGICAL HAZARD FACTORS AFFECTING CLAD WASTE MANAGEMENT

by

G. E. Zima

JuTy 30, 1976

BATTELLE

Pacific Northwest Laboratories

Richland, Washington 


\section{CONTENTS}

1.0 INTRODUCTION . . . . . . . . . . . . . . . . . . . . 1

2.0 RELATIVE IMPORTANCE OF VARIOUS NUCLEAR FUEL WASTE STREAMS . . •

3.0 SPENT FUEL RADIOACTIVITY AND RADIOLOGICAL HAZARD BURDENS. . . . . 5

4.0 COMPARISON OF VARIOUS INDICES FOR HIGH LEVEL WASTE AND CLAD WASTE. - 9

4.1 Volume Comparison for Various Densification Levels . . . . . 9

4.2 Radioactivity Comparison. . . . . . . . . . . . . 14

4.3 Radiological Hazard Comparison. . . . . . . . . . . . 21

4.4 Thermal Power Comparison. . . . . . . . . . . . . . 27

5.0 COMPARISON OF RADIOACTIVITY AND THERMAL POWER OF CLAD WASTE FOR REFERENCE FUEL ASSEMBLY AND DIABLO CANYON FUEL MODELS. . . . . . . 31

6.0 SOME TECHNICAL MEASURES OF THE WASTE MANAGEMENT PROBLEM OF CLAD WASTE RELATIVE TO HIGH LEVEL WASTE . . . . . . . . . . 33

7.0 CONCLUSION . . . . . . . . . . . . . . . . . . . . 35

8.0 REFERENCES . . . . . . . . . . . . . . . . . . . . 37 


\title{
A BRIEF ASSESSMENT OF SOME TECHNICAL AND RADIOLOGICAL HAZARD FACTORS AFFECTING CLAD WASTE MANAGEMENT
}

\author{
G. E. Zima
}

\subsection{INTRODUCTION}

Demonstration of a practicable management strategy for the principal predictable adverse by-products of nuclear energy, namely, the waste from mining, milling, fuel manufacture, reactor operations and fuel reprocessing, appears to be a prime impediment to general public acceptance of the nuclear energy source. Although all of the above phases of the nuclear energy process pose problems in minimizing the public hazard, the general problem is centered in the post-reactor discharge phases where there is a concentration of radioactive products within a broad spectrum of physico.chemical forms, a need to transport these products among the various sites pertaining to the nuclear fuel process/cycle, and a need for ultimate disposal of certain products which must recognize a public hazard span greater than several hundred thousand years.

The throwaway strategy of nuclear fuel management is wasteful of energy resources, both potential and expended. Assuming minimal destruction of the spent fuel assembly, it does, however, provide the most compact "natural" form for the spent fuel products. It also provides the highest radioactivity and thermal power densities, characteristics which are at some opposition to compactness with respect to the overall waste handling problem. With conservation of fissile products, various waste streams are generated in the reprocessing and fuel manufacturing plants which add both volume and physico. chemical diversity to the subjects of the nuclear fuel waste management problem. Of these streams, the so-called high level waste (HLW) and the clad waste streams carry the principal radiological hazard and thermal power burdens when considering post reactor-discharge times in excess of roughly a year and reasonable contamination factors. 
The specifics of the waste management problems associated with these two streams are dependent on the reactor type, the fuel type, the burnup, and in-reactor neutron flux distribution and history, the post-reactor discharge time, and the physico-chemical state imparted to the harmful components of the waste by the reprocessing and manufacturing operations specific to the waste.

In attempting to gain some measure of the relative importance of the high level and clad waste streams within the context of a reasonable nuclear power scenario, various technical and hazard indices are compared for the light water, enriched uranium fueled, reactor $[\operatorname{LWR}(U)]$. For the clad waste, two fuel models are used for the volume comparison, namely, the Reference Fuel Assembly (RFA) and the Diablo Canyon reference fuel model (DC). The more extensive data available for the Diablo Canyon model on radioactivity and thermal power are used in the comparison of these indices. Most of this review pertains to a burnup of 33GWD/MT because of the predominance of this particular burnup in waste management literature. A brief analys is is given of the effect of burnup and fuel model on certain clad waste characteristics.

The clad waste management problem will involve a number of factors, including: operational and public hazard analysis of all phases of clad waste handling and storage; justification and feasibility analysis of decontamination, densification, and useful product manufacture; the establishment of criteria for acceptable storage forms for clad waste over the time span bracketed by reactor discharge and ultimate disposal. Technico.economic analysis and progressive optimization are fundamental to the evolution of candidate waste management strategies for public appraisal. This report is submitted as a preliminary to technico-economic considerations of clad waste which are within the current responsibility of the Materials Department of the Pacific Northwest Laboratories 


\subsection{RELATIVE IMPORTANCE OF VARIOUS NUCLEAR FUEL WASTE STREAMS}

In a recent general review article on nuclear fuel waste management, Wolfe ${ }^{(1)}$ gives a fuel cycle waste projection for the year 2000 , based on a previous nuclear power scenario. (2) His summary is given in Table 1, which lists volume and radioactivity for various waste categories on annual and accumulation bases. These waste categories closely follow those given by Blomeke et al. (3) Considering the gross radioactivity (MCi), it is obvious that the high level waste dominates the waste problem. From a volume standpoint, that of the high level waste is trivial compared to a number of other, less dangerous, categories. The radioactivity of the clad waste on both annual and accumulation bases is roughly "equivalent" to the noble gases. As shown later, however, this comparison is strongly sensitive to the post-reactor discharge time and the assumed fission product and transuranics contamination of the clad waste. Furthermore, the radiological hazard is of greater significance than the gross radioactivity.

On the basis of the long range radiological hazard index, to be discussed later, the transuranics and fission products (excluding the noble gases, tritium and iodine isotopes) dominate the waste management problem. It is appropriate, therefore, to concentrate the following discussion on the two waste streams that will, collectively, carry the greatest burden in this respect under reasonable contamination assumptions, namely, the high level waste and the clad waste streams. $(4,5)$

The nuclear power projection used by wolfe ${ }^{(1)}$ assumes a mix of various reactor types. One such mix given in his forecast source ${ }^{(2)}$ is as follows for the year 2000:

\begin{tabular}{lc}
\multicolumn{1}{c}{ Type } & $\%$ of Total Insta1 led Capacity \\
\cline { 2 - 2 } LWR(PWR) & 51.0 \\
LWR(BWR) & 24.8 \\
HTGR & 9.6 \\
FBR & 14.6
\end{tabular}

Plutonium recycle is assumed to begin near the year 1980. 
TABLE 1. Fuel Cycle Wastes Projected for the Year $2000^{(1)}$

\begin{tabular}{|c|c|c|c|c|c|}
\hline Waste Category & $\begin{array}{l}\text { Annual Ge } \\
\text { Volume } \\
\left(10^{3} \mathrm{ft}^{3}\right) \\
\end{array}$ & $\begin{array}{l}\frac{\text { neration }}{\text { Activity }} \\
\text { (MCi) }\end{array}$ & $\begin{array}{l}\frac{\text { Accumul ated }}{\text { Volume }} \\
\left(10^{3} \mathrm{ft}^{3}\right) \\
\end{array}$ & $\begin{array}{c}\text { Inventory } \\
\text { Activity } \\
\text { (MCi) }\end{array}$ & $\begin{array}{c}\text { Metric } \\
\text { Tons of } \\
\text { Transuranics } \\
\end{array}$ \\
\hline$\frac{\text { High-level }}{\text { Solidified }}$ & 49 & 57,800 & 470 & 158,000 & 1,360 \\
\hline \multicolumn{6}{|l|}{ Transuranium Wastes } \\
\hline cladding hulls & 52 & 230 & 440 & 860 & 93 \\
\hline $\begin{array}{l}\text { misc. alpha, beta, } \\
\text { gamma solids }\end{array}$ & 340 & 6.7 & 3,000 & 27 & 0.6 \\
\hline alpha solids & 1,140 & 31 & 8,600 & 170 & 19 \\
\hline Beta-Gamma Wastes & & & & & \\
\hline noble gases & 2.4 & 230 & 21 & 1,500 & 0 \\
\hline iodine & 0.08 & 0.0008 & 0.7 & 0.007 & 0 \\
\hline LWR tritium & - & & 25,000 & 2.3 & 0 \\
\hline FP tritium & 9.3 & 14 & 85 & 92 & 0 \\
\hline $\begin{array}{l}\text { misc. beta, gamma } \\
\text { solids }\end{array}$ & 36,900 & 3.8 & 260,000 & 1.9 & 0 \\
\hline Ore Tailings & $1,600,000$ & 0.5 & $21,300,000$ & 6.9 & 98,300 \\
\hline
\end{tabular}

In the following discussion, the comparison of the high level waste and the clad waste is given as a function of the post-reactor discharge time (hereinafter abbreviated as $\theta$ ). Use of the time since discharge (generation) from the reprocessing plant as the time reference is common. (e.g.3) This particular formality requires a further specification of the time interval between reactor discharge and reprocessing for decay calculations, a possibly variable factor whose significance lies chiefly in the identification of the time of the physico.chemical transformation of the waste forms effected by reprocessing. 


\subsection{SPENT FUEL RADIOACTIVITY AND RADIOLOGICAL HAZARD BURDENS}

The spent fuel burden of the various fission derivatives is a logical base from which to consider the post-reactor discharge waste management prob$7 \mathrm{em}$. Table 2 presents gross radioactivity data for the various nuclide classes comprising the radioactivity burden of the spent fuel. Data are given on a MTU (metric ton of uranium charged to reactor) basis as a function of the post-reactor discharge time $(\theta)$. The table also gives the relative importance (\% of total) of the various nuclide classes. On a gross radioactivity basis, the fission products (FP's) dominate up to some point between 100 and 1000 years, the transuranics (TRU's) constituting the major balance over this interval and dominating out to roughly $10^{5}$ years, beyond which point uranium isotopes increase in radiological significance (e.g., about $96 \%$ by $10^{6}$ years). Data for this particular reactor system [LWR(U) reactor, Diablo Canyon fuel mode1, 33 MWD/MT burnup] were obtained from reported ORIGEN code calculations, $(3,6)$ correcting for uranium and plutonium depletion where necessary for the long term data. ${ }^{(6)}$ Long term light metal (LM) data were obtained by calculating decay constants for the principal long term LM's from short term

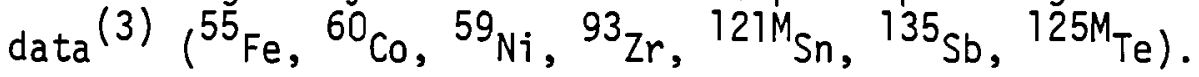

Table 3 presents the air radiological hazard index for the various nuclide classes as a function of $\theta$. The individual class radiological hazard index is defined as the aggregate of the volume $\left(\mathrm{m}^{3}\right)$ of air, or water, needed to bring the maximum permissible concentration (MPC) of the nuclides within the class to the level specified in 10 CFR $20 .{ }^{(7)}$ The overall radiological hazard index (sum over all nuclide classes) is given at the right side of the table. The lower portion of the table gives the relative importance (\% of total) of the various classes as a function of $\theta$. In contrast to Table 2 , it is noted that on the basis of the more significant radiological hazard index, the TRU's dominate from the outset of reactor discharge and constitute virtually $100 \%$ of the radiological hazard beyond roughly 100 years. MPC data were obtained from the latest source ${ }^{(7)}$ for individual nuclides and the radiological hazard index for a given nuclide class was obtained by computing the radiological hazard 
index for each nuclide within the class, using radioactivity data from sources previously cited. $(3,6)$ The relative importance data are plotted against $\theta$ in Figure 1.

TABLE 2. Spent Fuel Radioactivity Burden for Various Nuclide Classes

LWR (U) Reactor

33GWD/MT Burnup, $2.92+13 \mathrm{n} / \mathrm{cm}^{2}$ sec flux

Diablo Canyon Fuel Mode1

\begin{tabular}{|c|c|c|c|c|c|c|c|}
\hline & & & & $\mathrm{TU}^{(\mathrm{a})}$ & & & \\
\hline$\theta(y r)$ & $\begin{array}{l}\text { Noble } \\
\text { Gases }\end{array}$ & $3_{H}$ & I & FP's & TRU's & LM's & $\Sigma \mathrm{Ci} / \mathrm{MTU}$ \\
\hline 0.4 & $1.63+6^{(b)}$ & $6.92+2$ & $8.61+5$ & $1.36+8$ & $3.91+7$ & $1.42+5$ & $1.78+8$ \\
\hline 1.4 & $1.06+4$ & $6.54+2$ & $3.75-2$ & $2.21+6$ & $1.14+5$ & $1.00+4$ & $2.35+6$ \\
\hline 10.4 & $5.96+3$ & $3.94+2$ & $3.75-2$ & $3.12+5$ & $7.20+4$ & $2.4+3$ & $3.93+5$ \\
\hline 100 & $1.81+1$ & 2.47 & $3.75-2$ & $3.42+4$ & $1.39+4$ & $2.68+2$ & $4.81+4$ \\
\hline 1000 & $1.50-24$ & $2.35-22$ & $3.75-2$ & $2.09+1$ & $2.21+3$ & 4.24 & $2.23+3$ \\
\hline 10000 & & & $3.75-2$ & $1.99+1$ & $1.52+3$ & 3.95 & $1.54+3$ \\
\hline
\end{tabular}

Relative Radioactivity Importance of Various Nuclide Classes (\% of Total)

$\begin{array}{lccclll}0.4 & 9.2-1 & 3.9-4 & 4.8-1 & 7.6+1 & 2.2+1 & 8.0-2 \\ 1.4 & 4.5-1 & 2.8-2 & 1.6-6 & 9.4+1 & 4.9 & 4.3-1 \\ 10.4 & 1.5 & 1.0-1 & 9.6-6 & 8.0+1 & 1.8+1 & 6.1-1 \\ 100 & 3.8-2 & 5.1-3 & 7.8-5 & 7.1+1 & 2.9+1 & 5.6-1 \\ 1000 & - & - & 1.7-3 & 9.4-1 & 9.9+1 & 1.9-1 \\ 10000 & - & - & 2.4-3 & 1.3 & 9.9+1 & 2.6-1\end{array}$
a. Noble gases:
Iodine Isotopes: ${ }^{85} \mathrm{Kr},{ }^{131}{ }^{131} \mathrm{I},{ }_{\mathrm{Xe}},{ }^{131_{\mathrm{I}}}{ }^{133 \mathrm{Xe}}$

Fission Products (FP's): a11 except noble gases, iodine

b. $1.63+6=1.63 \times 10^{6}$

$1.50-24=1.50 \times 10^{-24}$, etc. 
TABLE 3. Spent Fuel Radiological Hazard Index for Various Nuclide Classes (Air)

$$
\left[\begin{array}{l}
\text { LWR (U) Reactor } \\
33 \text { GWD/MT Burnup, } 2.92+13 \mathrm{n} / \mathrm{cm}^{2} / \mathrm{sec} \text { flux } \\
\text { Diablo Canyon Fuel Mode } 1
\end{array}\right]
$$

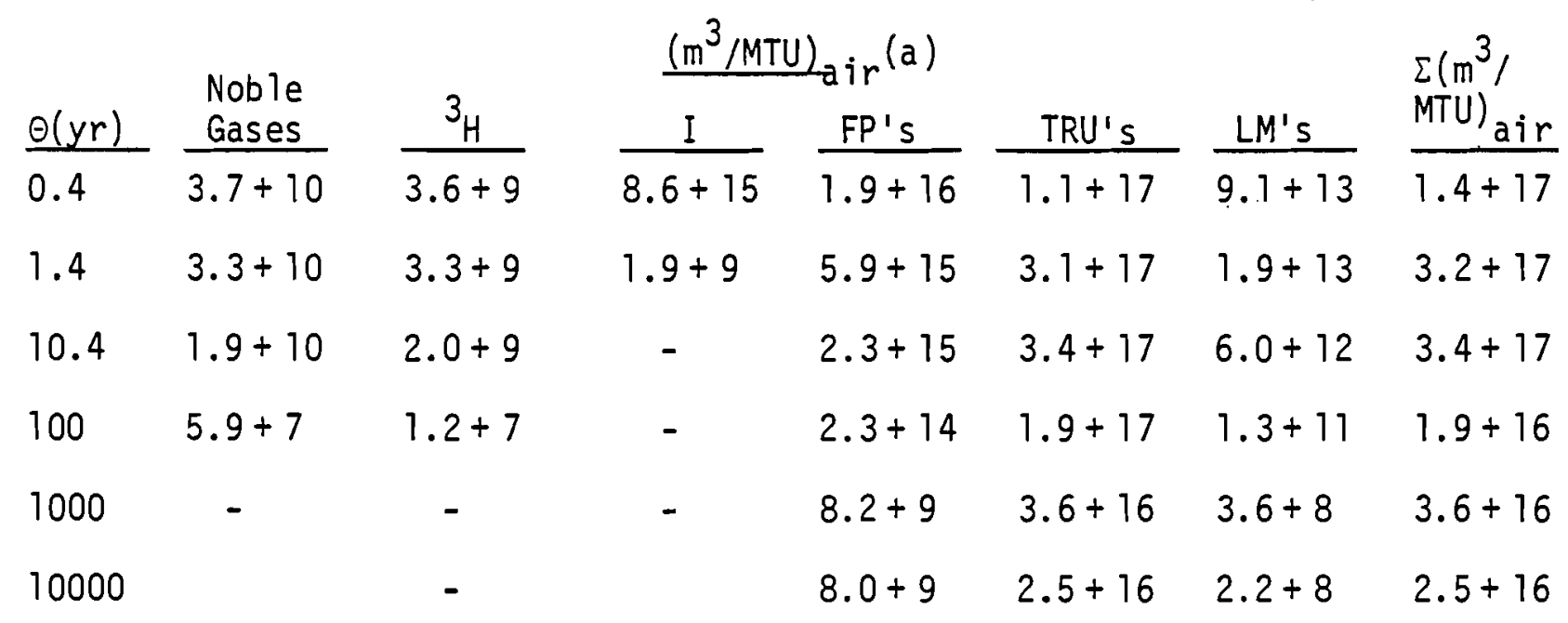

Relative Importance of Radiological Hazard of Various Nuclide Classes (Air) (\% of Tota 1$)$

$\begin{array}{lccllll}0.4 & 2.7-5 & 2.6-6 & 6.2 & 1.4+1 & 8.0+1 & 6.6-2 \\ 1.4 & 1.0-5 & 1.0-6 & 6.0-7 & 1.9 & 9.8+1 & 6.0-3 \\ 10.4 & 5.6-6 & 5.8-7 & 5.6-7 & 6.7-1 & 9.9+1 & 1.8-3 \\ 100 & 3.1-8 & 6.3-9 & 1.0-6 & 1.2-1 & \sim 1.0+2 & 6.8-5 \\ 1000 & - & - & 5.3-6 & 2.3-5 & \sim 1.0+2 & 1.0-6 \\ 10000 & - & - & 7.6-6 & 3.2-5 & \sim 1.0+2 & 8.8-7\end{array}$

a. $\mathrm{m}^{3}$ refers to air volume needed to bring nuclide concentration to MPC as specified in Ref. 7. The lowest MPC value of Ref. 7 was used for each nuclide in computing volume. 


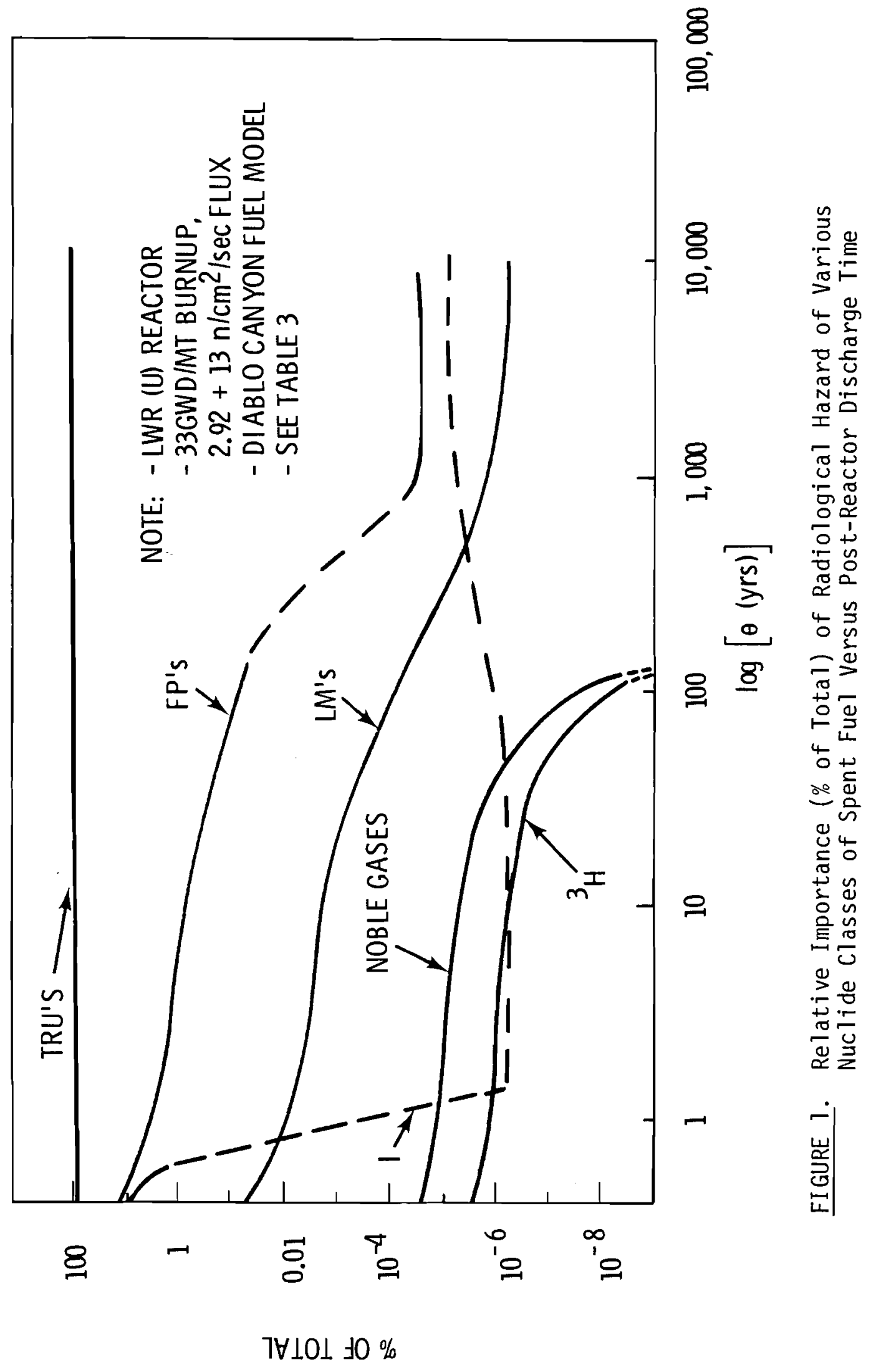




\subsection{COMPARISON OF VARIOUS INDICES FOR HIGH LEVEL WASTE AND CLAD WASTE}

\subsection{VOLUME COMPARISON FOR VARIOUS DENSIFICATION LEVELS}

In assessing clad waste characteristics, assumptions must be made as to the allotment of the various metallic components of the fuel assembly to the clad waste (i.e. the disassembly and sorting operations prior to the chopleach phase which "generates" the clad waste) and as to the pre-reactor exposure chemical composition of the metals assigned to the clad waste [basic as well as tramp elements (such as uranium) with radiological significance]. The LWR's are expected to bear the major nuclear power load up to at least the year 2000 (see Section 2.0), with roughly a 2:1 proportion of PWR to BWR reactor types within the LWR segment of nuclear power. Two fuel (clad waste) models which have been proposed for characterization of the clad waste from LWR's, using either enriched uranium or plutonium recycle fuel, are the Diablo Canyon Reference Fuel Model $(3,4,5,8)$ and the Reference Fuel Assembly. (9) The metallic (non-fuel) composition of these models is given in Table 4, together with the weight of clad waste per MTU (or MTHM) assigned to each model. The Zircaloy channels of the BWR fuel assemblies are excluded from the clad waste. The Diablo Canyon model represents essentially Zircaloy cladding $(\sim 93 \mathrm{w} / \mathrm{O})$ and Inconel spacers $(\sim 7 \mathrm{w} / \mathrm{o})$, while the Reference Fuel Assembly model includes some Type 304 stainless steel in a clad waste alloy mix comprised of $\mathrm{Zr}-4(88.6 \mathrm{w} / 0), 304$ SS ( $8.91 \mathrm{w} / 0)$, and Inconel-718 (2.45 w/0).

Densities, MTU specific volumes, and GWe.yr specific volumes are given in Table 5 for the Diablo Canyon (abbreviated as DC), the Reference Fue 1 Assembly (abbreviated as RFA) and the high level waste (abbreviated as HLW), for various forms of these wastes. Density and specific volume estimates were obtained from the table cited references.

Referring to the GWe.yr and MTU specific volume columns, the DC fuel model clad waste and the HLW are virtually equivalent on this basis for the die-compacted and vitrified forms, respectively.

Using the LWR nuclear power and fuel processing forecast given in ERDA-76-43, ${ }^{(11)}$ the total volume for the various forms of HLW and clad waste (abbreviated as $\mathrm{CW}$ ) are given in Table 6 , using specific volume data given 
TABLE 4. Metal (Non-Fue1) Compositions Assumed for Diablo Canyon and Reference Fuel Assembly Models for Clad Waste

$$
\text { Diablo Canyon Model }{ }^{(8)}
$$

$\begin{array}{lcc}\text { element } & \text { g/MT cladding } & \text { w/0 } \\ \text { carbon } & 66 & 0.0066 \\ \text { aluminum } & 399 & 0.0399 \\ \text { silicon } & 66 & 0.0066 \\ \text { titanium } & 664 & 0.0664 \\ \text { vanadium } & 27 & 0.0027 \\ \text { chromium } & 13,500 & 1.35 \\ \text { manganese } & 66 & 0.0066 \\ \text { iron } & 13,800 & 1.38 \\ \text { cobalt } & 200 & 0.02 \\ \text { nickel } & 35,280 & 3.53 \\ \text { niobium } & 3520 & 0.352 \\ \text { molybdenum } & 2100 & 0.210 \\ \text { tin } & 13,900 & 1.39 \\ \text { zirconium } & 9.2 \times 10^{5} & 92.0 \\ \text { (includes Inconel spacers/grids; assumes about } 7 \mathrm{w} / 0 \text { Inconel) } \\ \text { 27l kg clad waste/MTU }\end{array}$

Reference Fuel Assembly Model ${ }^{(9)}$

\begin{tabular}{|c|c|c|c|}
\hline al1oy & element & g/assembly & $w / 0^{(a)}$ \\
\hline $2 r-4$ & $\begin{array}{l}\mathrm{Sn} \\
\mathrm{Fe} \\
\mathrm{Cr} \\
\mathrm{Zr}\end{array}$ & $\begin{array}{l}1430 \\
202 \\
112 \\
87,850\end{array}$ & $\begin{array}{l}1.42 \\
6.74 \\
2.27 \\
87.0\end{array}$ \\
\hline $\begin{array}{l}\text { Type } 304 \\
\text { SS }\end{array}$ & $\begin{array}{l}\mathrm{Cr} \\
\mathrm{Ni} \\
\mathrm{Mn} \\
\mathrm{Si} \\
\mathrm{P} \\
\mathrm{C} \\
\mathrm{Se} \\
\mathrm{S} \\
\mathrm{Fe}\end{array}$ & $\begin{array}{l}1710 \\
811 \\
180 \\
90 \\
18 \\
14 \\
14 \\
5 \\
6160\end{array}$ & $\begin{array}{l}\overline{2} .10 \\
0.178 \\
0.0891 \\
0.0178 \\
0.0149 \\
0.0139 \\
0.0050 \\
-\end{array}$ \\
\hline $\begin{array}{l}\text { Incone 1- } \\
718\end{array}$ & $\begin{array}{l}\mathrm{Ni} \\
\mathrm{Cr} \\
\mathrm{Fe} \\
\mathrm{Nb} / \mathrm{Ta} \\
\mathrm{Mo} \\
\mathrm{Co} \\
\mathrm{Ti} \\
\mathrm{Al} \\
\mathrm{C}\end{array}$ & $\begin{array}{l}1310 \\
470 \\
446 \\
124 \\
74 \\
20 \\
20 \\
15 \\
1\end{array}$ & $\begin{array}{l}- \\
- \\
- \\
0.123 \\
0.0733 \\
0.0198 \\
0.0198 \\
0.0149 \\
-\end{array}$ \\
\hline
\end{tabular}

$325 \mathrm{~kg} \mathrm{Clad}$ Waste/MTHM

a. First entry for element is sum for all entries of element 
in Table 5. The extremes (high-low) in the volume forecast for the HLW and clad waste are plotted versus the year in Figure 2 . It is seen that there is considerable overlap in the volume factor for the HLW and clad waste streams, depending on the particular forms of these wastes. As noted previously, with the clad waste in the die-compacted form ${ }^{(4)}$ and the HLW in the vitrified form, $(10)$ the GWe.yr specific volumes of these wastes are virtually equal, as reflected in columns 2 and 8 of Table 6 .

TABLE 5. Specific Volume (MTU and GWe.yr Bases) for Various Waste Forms

\begin{tabular}{|c|c|c|c|c|c|}
\hline Waste & Form & $\mathrm{g} / \mathrm{cm}^{3}$ & $\mathrm{~m}^{3} / \mathrm{MTU}$ & $\mathrm{m}^{3} / \mathrm{GWe} \cdot y r^{(a)}$ & Reference \\
\hline CLAD (DC) & uncomp. & 1.2 & $2.3-1$ & 7.8 & 5 \\
\hline CLAD (DC) & rolled & 3.3 & $8.2-2$ & 2.8 & 5 \\
\hline CLAD (DC) & compacted & 4.5 & $6.0-2$ & 2.0 & 5 \\
\hline CLAD (DC) & ingot & 6.5 & $4.2-2$ & 1.4 & 5 \\
\hline CLAD (RFA) & uncomp. & 1.0 & $3.3-1$ & $1.1+1$ & 9 \\
\hline CLAD (RFA) & rolled & 3.4 & $9.7-2$ & 3.3 & $\begin{array}{l}\text { Est. from } \\
\text { Ref. } 5 \text { data }\end{array}$ \\
\hline CLAD (RFA) & compacted & 4.6 & $7.0-2$ & 2.4 & $"$ \\
\hline CLAD (RFA) & ingot & 6.6 & $4.9-2$ & 1.7 & $"$ \\
\hline HLW & \multirow{2}{*}{\multicolumn{2}{|c|}{$\begin{array}{l}1 \text { iquid conc. } \\
\text { calcine (b) }\end{array}$}} & $3.8-1$ & $1.3+1$ & 9 \\
\hline HLW & & & $5.0-2$ & 1.7 & 10 \\
\hline HLW & \multicolumn{2}{|c|}{ vitrified $(c)$} & $6.0-2$ & 2.0 & 10 \\
\hline HLW & \multicolumn{2}{|c|}{$\begin{array}{l}\text { metal-HLW } \\
\operatorname{compact}(d)\end{array}$} & $3.0-2$ & 1.0 & 10 \\
\hline
\end{tabular}

a. $\mathrm{m}^{3} /$ GWe.yr $=\mathrm{m}^{3} \mathrm{MTU} \times 34.03($ MTU/GWe.yr) [33 GWD/MT burnup, LWR(U)]

b. range for calcine $=0.04-0.06 \mathrm{~m}^{3} / \mathrm{MTU}$

c. range for vitrified $=0.04-0.08 \mathrm{~m}^{3} /$ MTU

d. range for metal-HLW compacts (molten metal casting, powdered metal sintering) $=0.03-0.08 \mathrm{~m}^{3} /$ MTU (low value used for table and plots) 


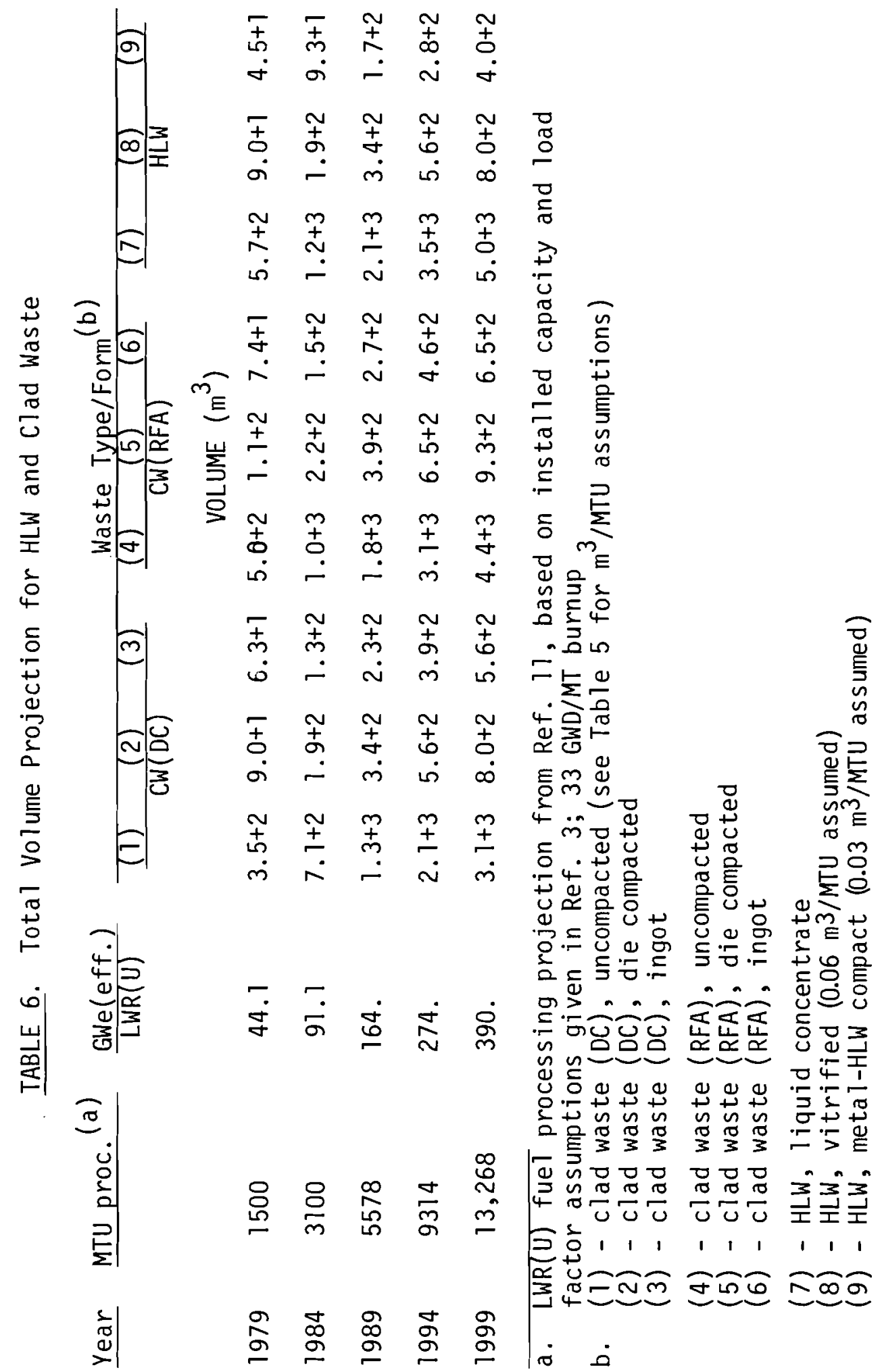




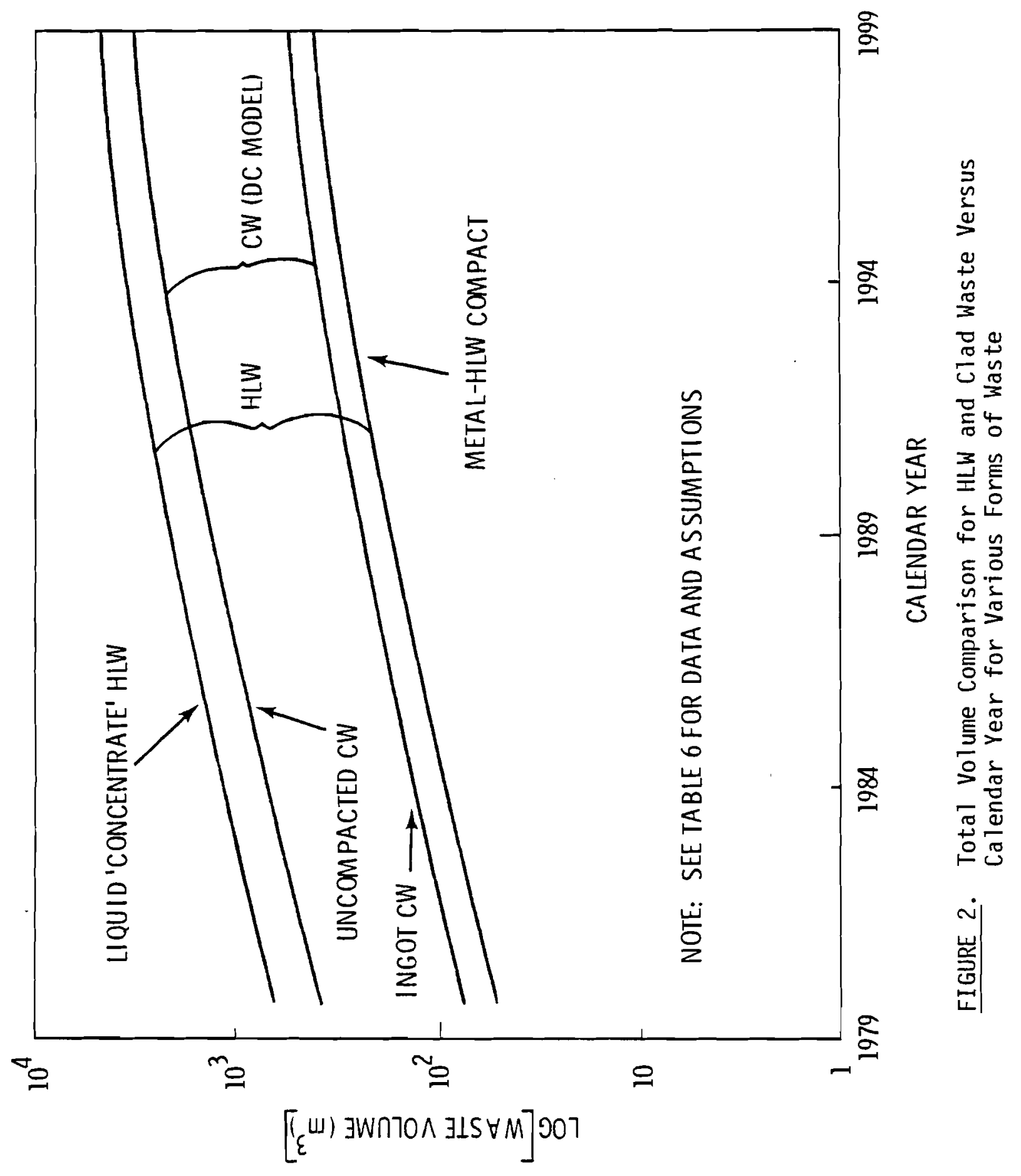




\subsection{RADIOACTIVITY COMPARISON}

Again using the $\operatorname{LWR}(U)$ reactor and the Diablo Canyon fuel model, the aggregate radioactivity burden for the HLW and clad waste streams are compared for the various nuclide classes in Table 7 . The contamination assumptions for the HLW and clad waste are given at the bottom of the table. These have been used extensively in ORNL analysis of nuclear waste and are believed to represent fairly realistic conditions. Radioactivity is given for the various classes on a MTU basis and for the total on a GWe.yr basis as well. The aggregate data on a GWe.yr basis are plotted versus $\Theta$ in Figure 3 for the HLW and the clad waste.

Using the GWe.yr specific volume data given in Table 5 for the HLW and the clad waste, and the aggregate radioactivity data given in Table 7 , radioactivity "densities" $\left(\mathrm{MCi} / \mathrm{m}^{3}\right)$ were computed for these wastes for the dens $\mathrm{i}$ fication extremes given in Table 5. These data are plotted in Figure 4 versus $\theta$. On a GWe.yr basis (Figure 3 ), it is seen that the HLW retains higher aggregate radioactivity burdens throughout the span of $\theta$. On a "density" basis (Figure 4), there is some overlap of the HLW and the clad waste bands, starting at about 10,000 years.

In view of the current Federal restrictions on transuranics (TRU's) contaminated waste, it is interesting to estimate the TRU's burden of the Diablo Canyon fuel model clad waste as a function of $\theta$ for several TRU's contamination levels (percent of spent fuel TRU's burden in clad waste). These data are given in Table 8 for 0.1 and $0.05 \mathrm{w} / 0$ contamination levels (the latter value being used in the present HLW clad waste comparison). TRU's contamination is given in terms of nCi per gram of clad waste in Table 8 . Table 9 gives the decontamination factors ( $D F^{\prime} s$ ) corresponding to the current $10 \mathrm{nCi} / \mathrm{gm}$ criterion as a function of $\theta$, for the two contamination levels. These values for 1.4 and 10.4 years are in reasonable agreement with DF's estimated by Dillon et al ${ }^{(12)}$ for similar clad waste. The data of Table 9 are plotted versus $\Theta$ in Figure 5 .

Decontamination data for clad waste are very sparce. Blomeke and Perona (5) reported that repeated leaching of a Zircaloy plus stainless steel clad waste from highly irradiated fuel in a $8-10 \mathrm{M} \mathrm{HNO}_{3}$ solution, followed by water rinsing 
TABLE 7. Aggregate Radioactivity According to Nuclide Class For HLW and Clad Waste CLAD WASTE (DC Model) ${ }^{(a)}$

\begin{tabular}{|c|c|c|c|c|c|c|}
\hline$\underline{\theta(y r)}$ & $\begin{array}{c}\text { TRU's } \\
\text { (Ci/MTU) } \\
\end{array}$ & FP & LM & $\underline{\Sigma(\mathrm{Ci} / \mathrm{MTU})}$ & $\underline{\Sigma(\mathrm{MCi} / \mathrm{MTU})}$ & $\sum M C i / G W e-y r$ \\
\hline 1.4 & $6.10+1$ & $8.40+2$ & $7.78+3$ & $8.68+3$ & $8.68-3$ & $2.95-1$ \\
\hline 10.4 & $4.35+1$ & $1.56+2$ & $2.39+3$ & $2.59+3$ & $2.59-3$ & $8.81-2$ \\
\hline 100 & 6.95 & $1.71+1$ & $2.68+2$ & $2.92+2$ & $2.92-4$ & $9.94-2$ \\
\hline 1000 & 1.11 & $1.05-2$ & 4.24 & 5.36 & $5.36-6$ & $1.82-4$ \\
\hline 10000 & $7.60-1$ & $9.95-3$ & 3.95 & 4.72 & $4.72-6$ & $1.67-4$ \\
\hline \multirow[t]{2}{*}{100000} & $7.45-2$ & $7.65-3$ & 3.95 & 4.03 & $4.03-6$ & $1.37-4$ \\
\hline & & & & $H L W^{(b)}$ & & \\
\hline 1.4 & $7.28+3$ & $1.68+6$ & & $1.69+6$ & 1.69 & $5.75+1$ \\
\hline 10.4 & $2.35+3$ & $3.12+5$ & & $3.14+5$ & $3.14-1$ & $1.07+1$ \\
\hline 100 & $3.10+2$ & $3.42+4$ & & $3.45+4$ & $3.45-2$ & 1.17 \\
\hline 1000 & $7.82+1$ & $2.09+1$ & & $9.91+1$ & $9.91-5$ & $3.37-3$ \\
\hline 10000 & $2.28+1$ & $1.99+1$ & & $4.27+1$ & $4.27-5$ & $1.45-3$ \\
\hline \multicolumn{2}{|l|}{100000} & $1.53+1$ & & $1.80+1$ & $1.80-5$ & $6.13-4$ \\
\hline \multicolumn{7}{|c|}{$\begin{array}{l}\text { a. Diablo Canyon fuel model (see Table 4) } \\
\text { LWR(U) reactor, } 33 \mathrm{GWD} / \mathrm{MT} \text { burnup; } 34.03 \mathrm{MTU} / \mathrm{GWe} \cdot \mathrm{yr} \\
0.05 \mathrm{~W} / 0 \text { spent fuel } U \text { and TRU's in clad waste (data from Ref. } 3,6 \text { ) } \\
\frac{100 \mathrm{~W} / 0 \text { light metal (LM) in clad waste }}{}\end{array}$} \\
\hline
\end{tabular}




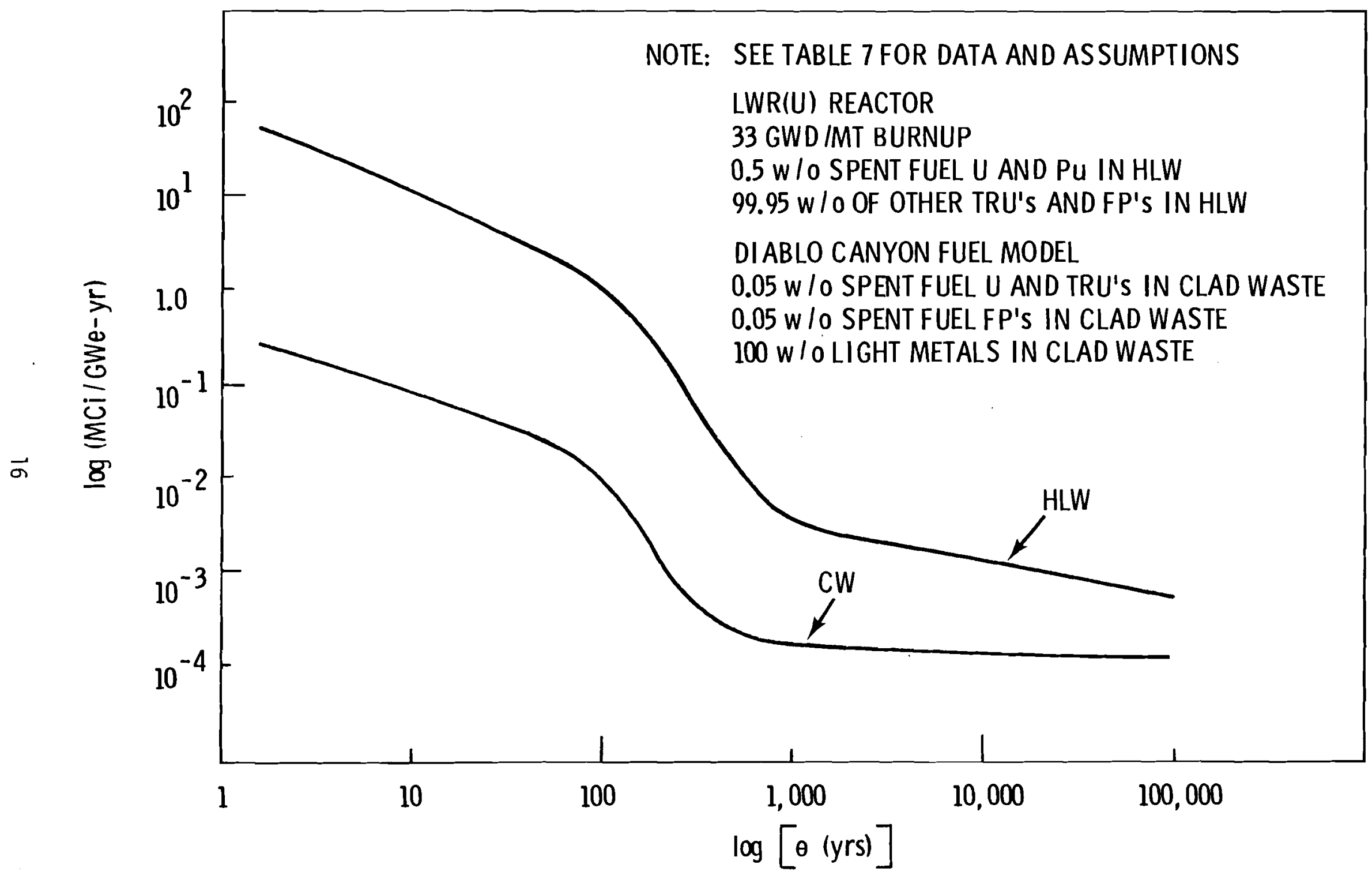

FIGURE 3. Specific Radioactivity (GWe.yr Basis) Burden for HLW and Clad Waste Versus Post-Reactor Discharge Time 


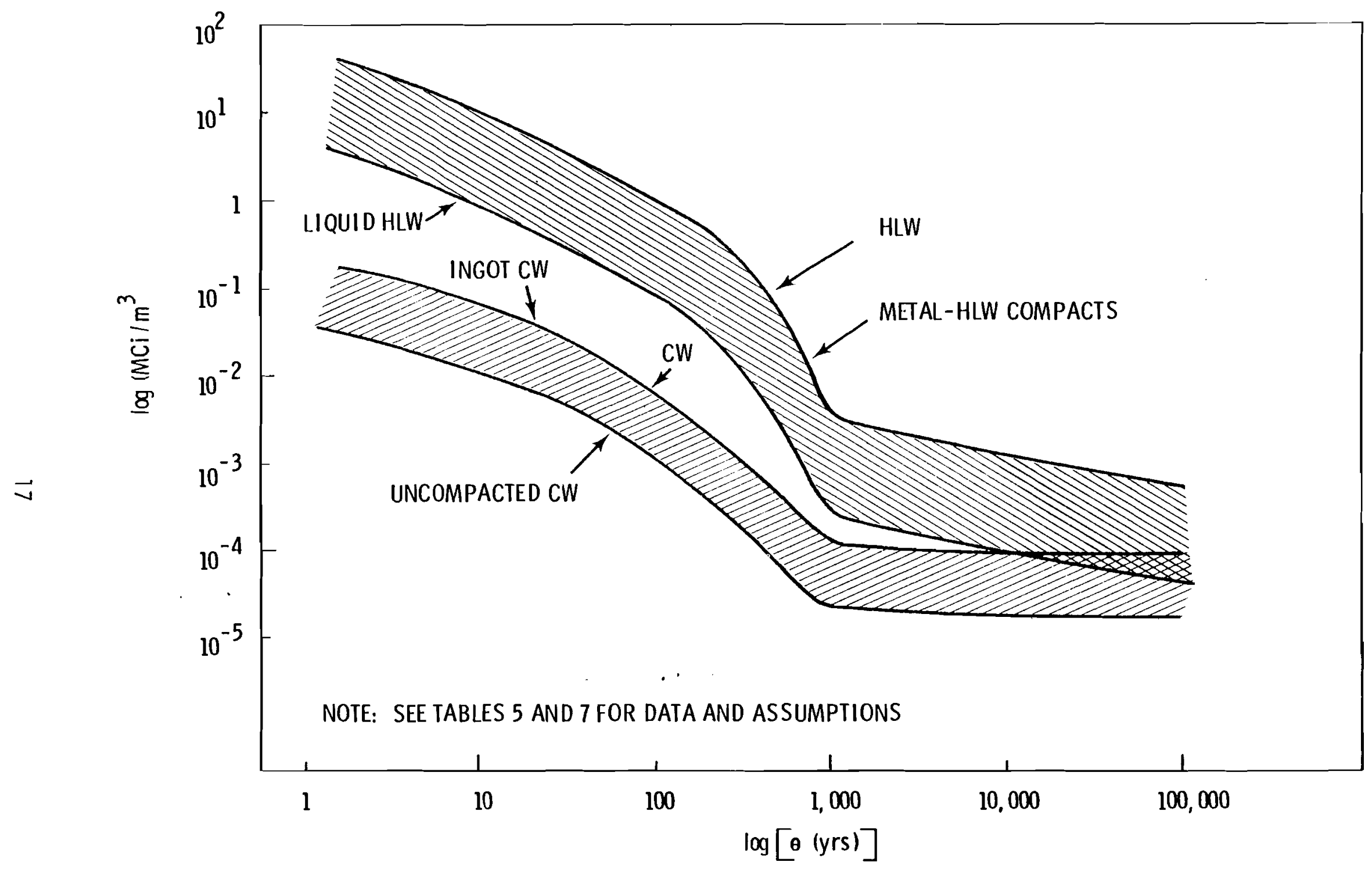

FIGURE 4. Comparison of Aggregate Radioactivity Densities for HLW and Clad Waste Versus Post-Reactor Discharge Time 
TABLE 8. TRU's Burden ( $\mathrm{nCi} / \mathrm{g}$ ) in $\mathrm{Cl}$ ad waste for Several Contamination Levels

\begin{tabular}{|c|c|c|c|c|}
\hline$\theta(y r)$ & $\begin{array}{l}100 \%(S F)^{(a)} \\
(M C i / M T U)_{T R U ' s} \\
\end{array}$ & $\begin{array}{l}100 \%(\mathrm{SF})^{(\mathrm{b})} \\
(\mathrm{nCi} / \mathrm{g})_{\mathrm{TRU}} \mathrm{s} / \mathrm{CW}\end{array}$ & $\begin{array}{c}0.10 \mathrm{w} / \mathrm{o} \\
(n \mathrm{nci} \mathrm{g} / \mathrm{g}) \mathrm{TRU} \mathrm{T}^{\prime} \mathrm{s} / \mathrm{CW} \\
\end{array}$ & $\begin{array}{c}0.05 \mathrm{w} / 0 \\
(\mathrm{nCi} / \mathrm{g})_{\mathrm{TRU}} \mathrm{s} / \mathrm{CW}\end{array}$ \\
\hline 1.4 & $1.22-1$ & $4.50+8$ & $4.50+5$ & $2.25+5$ \\
\hline 10.4 & $8.70-2$ & $3.21+8$ & $3.21+5$ & $1.61+5$ \\
\hline 100 & $1.39-2$ & $5.12+7$ & $5.12+4$ & $2.56+4$ \\
\hline 1000 & $2.19-3$ & $8.08+6$ & $8.08+3$ & $4.04+3$ \\
\hline 10000 & $1.50-3$ & $5.54+6$ & $5.54+3$ & $2.77+3$ \\
\hline 100000 & $1.13-4$ & $4.17+5$ & $4.58+3$ & $2.29+3$ \\
\hline
\end{tabular}

a. data from Ref. 6 (p.2.c.7), bringing Pu isotopes to spent fuel (SF) level

b. for $D C$ fuel model, IMCi $/$ MTU per $271 \mathrm{~kg} C W / M T U=3.69+9 \mathrm{nCi} / \mathrm{g} \mathrm{CW}$

TABLE 9. Decontamination Factors (DF) Corresponding to $10 \mathrm{nCi} / \mathrm{g}$ Criterion for Several Contamination Values

\begin{tabular}{|c|c|c|}
\hline \multirow[b]{2}{*}{$\theta(y r)$} & \multicolumn{2}{|c|}{$\mathrm{DF}_{10 \mathrm{nCi} / \mathrm{g}}(\mathrm{a})$} \\
\hline & $\underline{0.1 \mathrm{w} / \mathrm{o}^{(\mathrm{b})}}$ & $0.05 \mathrm{w} / \mathrm{O}$ \\
\hline 1.4 & $4.5+4$ & $2.3+4$ \\
\hline 10.4 & $3.2+4$ & $1.6+4$ \\
\hline 100 & $5.1+3$ & $2.6+3$ \\
\hline 1000 & $8.1+2$ & $4.0+2$ \\
\hline 10000 & $5.5+2$ & $2.8+2$ \\
\hline 100000 & $4.6+2$ & $2.3+2$ \\
\hline
\end{tabular}

a. $\quad D F=$ amount in/amount out $=$ amount in $(\mathrm{nCi} / \mathrm{g}) / 10 \mathrm{nCi} / \mathrm{g}$

b. amount of contamination of clad waste by spent fuel TRU's 


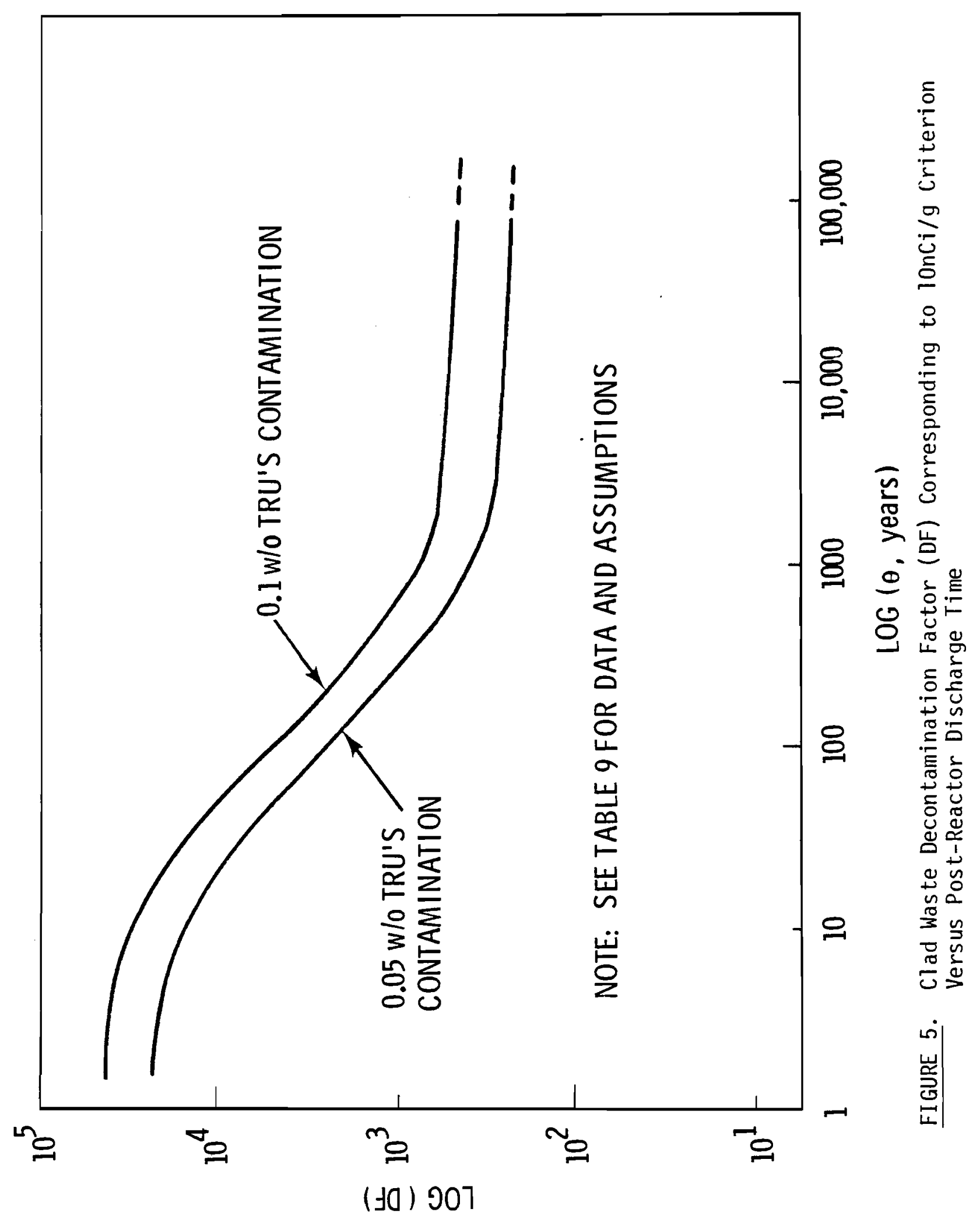


after each leaching, reduced the Pu activity to about $700 \mathrm{nCi} / \mathrm{g}$, an observation which tends to highlight the severity of the $10 \mathrm{nCi} / \mathrm{g}$ restriction on burial of TRU's contaminated waste. Dillon et al ${ }^{(12)}$ report on BNWL decontamination work on Zircaloy, illustrating the physico.chemical complexity of the decontamination process.

As noted in the previous data compilations for the HLW and clad waste comparison, it is assumed that a certain fraction of the spent fuel $\underline{U}$ and $P u$ (namely $0.5 \mathrm{w} / \mathrm{o}$ for this comparison) is carried over in the HLW stream, and virtually all other nuclides from ${ }^{207} \mathrm{~T} 1$ to ${ }^{247} \mathrm{Cm}$ as wel1. $(3,4,6)$ The clad waste is assumed to carry a certain fraction (namely, $0.05 \mathrm{w} / 0$ for this comparison) of the total spent fuel burden of nuclides from ${ }^{207} \mathrm{Tl}$ to ${ }^{247} \mathrm{Cm}$. Considering the intimate conjunction of the cladding and the fuel, and the processes which generate the HLW, these appear to be reasonable assumptions, though not necessarily supportive of the numerical values of the contamination.

Using previously cited radioactivity data sources, and a spent fuel $U$ and Pu recovery factor of 0.995 , the TRU's activity fraction together with those of the uranium isotopes and the remaining isotopes from ${ }^{207} \mathrm{Tl}$ to ${ }^{247} \mathrm{Cm}$ are given in Table 10 as a function of $\theta$. These data show that the TRU's activity dominates the radioactivity burden of both the HLW and clad waste streams out to roughly 10,000 years. Under the above contamination and fractionation assumptions, TRU's activity fractions for the HLW and clad waste are virtually equal out to this time. The uranium isotope activity fraction becomes dominant for the clad waste between $10^{5}$ and $10^{6}$ years. 
TABLE 10. Radioactivity Fractions for Various Nuclide Groups Within the Class $207 \mathrm{Tl}$ to $247 \mathrm{Cm}$ for HLW and Clad Waste

\begin{tabular}{|c|c|c|c|c|c|c|}
\hline \multirow[b]{2}{*}{$\theta(y r s)$} & \multicolumn{6}{|c|}{$\left[\begin{array}{l}\text { LWR }(U) \text { Reactor, 33MWD/MT Burnup } \\
\text { Diablo Canyon Fuel Model }\end{array}\right]$} \\
\hline & TRU'S & $\mathrm{U}$ & Other & $\overline{T R U^{\prime} \mathrm{s}}$ & $U$ & other \\
\hline 0.4 & 1.00 & 0 & 0 & 1.00 & 0 & 0 \\
\hline 1.4 & 1.00 & 0 & 0 & 1.00 & 0 & 0 \\
\hline 10.4 & 1.00 & 0 & 0 & 1.00 & 0 & 0 \\
\hline 100 & 1.00 & 0 & 0 & 1.00 & 0 & 0 \\
\hline 1000 & 0.995 & 0.005 & 0 & 0.987 & 0.005 & 0.008 \\
\hline $10^{4}$ & 0.978 & 0.003 & 0.019 & 0.993 & 0.002 & 0.005 \\
\hline $10^{5}$ & 0.343 & 0.062 & 0.595 & 0.763 & 0.228 & 0.009 \\
\hline $10^{6}$ & 0.085 & 0.093 & 0.822 & 0.004 & 0.949 & 0.047 \\
\hline $10^{7}$ & 0.077 & 0.111 & 0.812 & 0 & 0.962 & 0.038 \\
\hline $10^{8}$ & 0 & 0.143 & 0.857 & 0 & 0.971 & 0.029 \\
\hline $10^{9}$ & 0 & 0.139 & 0.861 & 0 & 0.969 & 0.031 \\
\hline
\end{tabular}

a. assuming contamination by $0.5 \mathrm{w} / \mathrm{O} U$ and $\mathrm{Pu}$ of spent fuel pius $99.95 \mathrm{w} / 0$ of other isotopes from $207 \mathrm{Tl}$ to $247 \mathrm{Cm}$ (see Ref. $3,4,6$ )

b. assuming contamination by $0.05 \mathrm{w} / 0$ of spent fue 1 isotopes from $207 \mathrm{Tl}$ to $247 \mathrm{Cm}$ 


\subsection{RADIOLOGICAL HAZARD COMPARISON}

Using the radiological hazard index discussed previously, the indices for the various nuclide classes are given for the clad waste in Table 11, and for the HLW in Table 12. Data are presented on both MTU and GWe.yr bases. Data sources and calculation technique are the same as cited in Section 3.0. Both air and water values are given, noting that the lowest air/water MPC value for a given nuclide was used in the calculation. Radiological hazard index values (MTU basis) for air and water, for the various nuclide classes, are plotted versus $\theta$ in Figure 6 for the clad waste. Figure 7 presents similar information for the HLW. It is apparent that these data exhibit fairly complex time profiles and that statements about the relative radiological importance of various nuclides in HLW and clad waste must be qualified by a corresponding time specification.

Using the MTU specific volume data for HLW and clad waste given in Table 5 for various forms of these wastes, the air hazard "densities" were computed for the TRU's and the fission products (FP's), for the indicated range of densification for the HLW and the clad waste. These data are plotted in Figure 8 versus $\theta$. For the assumed contamination (see footnotes in Tables 11 and 12) it is seen that, depending on the densification, the critical TRU's radiological "densities" for the HLW and the clad waste can be quite comparable over a broad range of $\theta$. Although there is substantially greater difference in the FP data, appreciation of the practical significance of this difference from a waste management standpoint would require more comprehensive analysis of the radiological (more generally, the biological) hazard aspect.

Under the contamination assumptions of this comparison, and on the basis of the radiological hazard index, it appears evident that the waste management problem for clad waste can be comparable in severity to that of the HLW over a $\theta$ range which extends well into the ultimate disposal regime of waste management. 
TABLE 1. Radiological Hazard Index for Clad Waste According to Nuclide Class

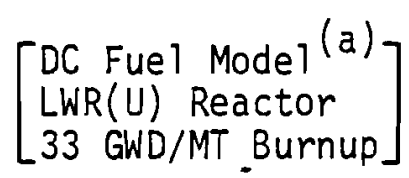

$\mathrm{m}^{3} /$ MTU Basis $(b)$

\begin{tabular}{|c|c|c|c|c|c|c|c|c|}
\hline \multirow[b]{2}{*}{$\theta(y r)$} & \multicolumn{2}{|c|}{ TRU's } & \multicolumn{2}{|c|}{ FP'S } & \multicolumn{2}{|c|}{ LM'S } & \multirow[b]{2}{*}{$\sum A i r$} & \multirow[b]{2}{*}{ EWater } \\
\hline & $\overline{A i r}$ & Water & Air & Water & $\overline{A i r}$ & Water & & \\
\hline 4 & $.5+14$ & $8.5+5$ & $3.0+12$ & $1.6+8$ & $1.9+13$ & $2.1+8$ & $1.7+14$ & $3.7+8$ \\
\hline 0.6 & $7+14$ & $6.5+5$ & $.2+12$ & $1.1+8$ & $6.0+12$ & $7.4+71$ & $1.8+14$ & $1.9+8$ \\
\hline 0 & $.5+13$ & $2.4+5$ & $1.2+11$ & $1.1+7$ & $1.3+11$ & $8.7+69$ & $9.5+13$ & $2.0+7$ \\
\hline 00 & $.8+13$ & $4.2+4$ & $4.1+6$ & $4.0+1$ & $3.6+8$ & $2.8+41$ & $1.8+13$ & $7.0+4$ \\
\hline, 000 & $1.3+13$ & $2.6+4$ & $4.0+6$ & $4.0+1$ & $2.2+8$ & $1.9+41$ & $1.3+13$ & $4.5+4$ \\
\hline
\end{tabular}

$\mathrm{m}^{3} /$ GWe.yr Basis $(\mathrm{c})$

$\begin{array}{lllllllll}1.4 & 5.1+15 & 2.9+7 & 1.0+14 & 5.4+9 & 6.5+14 & 7.2+9 & 5.0+15 & 1.3+10 \\ 10.4 & 5.8+15 & 2.2+7 & 4.1+13 & 3.7+9 & 2.0+14 & 2.5+9 & 6.0+15 & 6.2+9 \\ 100 & 3.2+15 & 8.2+6 & 4.1+12 & 3.7+8 & 4.4+12 & 3.0+8 & 3.2+15 & 6.8+8 \\ 1000 & 6.1+14 & 1.4+6 & 1.4+8 & 1.4+3 & 1.2+10 & 9.5+5 & 6.1+14 & 2.4+6 \\ 10,000 & 4.4+14 & 8.8+5 & 1.4+8 & 1.4+3 & 7.5+9 & 6.5+5 & 4.4+14 & 1.5+6\end{array}$

\footnotetext{
a. $\frac{0.05 \mathrm{w} / 0 \text { spent fuel TRU's and } U \text { in clad waste }}{0.05 \mathrm{~W} / 0 \text { spent fuel } F P^{\prime} \mathrm{s} \text { in clad waste }}$ $100 \mathrm{w} / 0 \mathrm{LM}^{\prime} \mathrm{s}$ in clad waste

b. $m^{3}$ refers to volume (air/water) needed to bring given nuclide concentration to MPC limit as specified in Ref. 7

c. $\mathrm{m}^{3} / \mathrm{GWe} \cdot \mathrm{yr}=\mathrm{m}^{3} / \mathrm{MTU} \times 34.03 \mathrm{MTU} / \mathrm{GWe} \cdot \mathrm{yr}$
} 
TABLE 12. Radiological Hazard Index for HLW According to Nuclide Class

\begin{tabular}{|c|c|c|c|c|c|c|}
\hline \multirow[b]{2}{*}{$\theta(y r)$} & \multicolumn{6}{|c|}{$\begin{array}{l}\text { LWR(U) Reactor (a) } \\
33 \text { GWD/MT Burnup } \\
\mathrm{m}^{3} / \text { MTU Basis }{ }^{(b)}\end{array}$} \\
\hline & \multicolumn{2}{|c|}{ TRU's } & \multicolumn{2}{|c|}{ FP's } & $\sum$ Air & $\sum$ Water \\
\hline 0.4 & $\overline{1.4+16}$ & $\overline{1.3+9}$ & $\overline{1.0+16}$ & $\overline{4.5+11}$ & $\overline{2.4+16}$ & $\overline{4.5+11}$ \\
\hline 3.4 & $9.8+15$ & $3.9+8$ & $3.4+15$ & $2.7+11$ & $1.3+16$ & $2.7+11$ \\
\hline 10.4 & $8.0+15$ & $3.0+8$ & $2.3+15$ & $2.1+11$ & $1.0+16$ & $2.1+11$ \\
\hline 100 & $1.9+15$ & $6.4+7$ & $2.4+14$ & $2.3+10$ & $2.1+15$ & $2.3+10$ \\
\hline 1000 & $4.4+14$ & $1.6+7$ & $8.4+9$ & $8 \cdot 3+4$ & $4.4+14$ & $1.6+7$ \\
\hline 10,000 & $1.6+14$ & $3.7+6$ & $8.0 \div 9$ & $8.0+4$ & $1.6+14$ & $3.8+6$ \\
\hline & & & GWe.yr & $\operatorname{sis}(c)$ & & \\
\hline 0.4 & $4.8+17$ & $4.4+10$ & $3.4+17$ & $1.5+13$ & $8.2+17$ & $1.5+13$ \\
\hline 3.4 & $3.3+17$ & $1.3+10$ & $1.2+17$ & $9.2+12$ & $4.5+17$ & $9.2+12$ \\
\hline 10.4 & $2.7+17$ & $1.0+10$ & $7.8+16$ & $7.2+12$ & $3.5+17$ & $7.2+12$ \\
\hline 100 & $6.5+16$ & $2.2+9$ & $8.2+15$ & $7.8+11$ & $7.3+16$ & $7.8+11$ \\
\hline 1000 & $1.5+16$ & $5.4+8$ & $2.9+11$ & $2.8+6$ & $1.5+16$ & $5.4+8$ \\
\hline 10,000 & $5.4+15$ & $1.3+8$ & $2.7+11$ & $2.7+6$ & $5.4+15$ & $1.3+8$ \\
\hline
\end{tabular}

a. $0.5 \mathrm{w} / \mathrm{O}$ of spent fuel $\mathrm{Pu}$ and $\mathrm{U}$ in $\mathrm{HLW}$ $99.95 \mathrm{~W} / 0$ of other spent fuel TRU's in HLW all tritium, noble gases removed from HLW $99.9 \mathrm{w} / 0$ halogen FP's removed from HLW 99.95 w/o of other FP's in HLW

b. $\mathrm{m}^{3}$ refers to volume (air/water) needed to bring given nuclide concentration to MPC limit as specified in Ref. 7

c. $\mathrm{m}^{3} /$ GWe $\cdot y r=\mathrm{m}^{3} /$ MTU $\times 34.03$ MTU/GWe $\cdot y r$ 


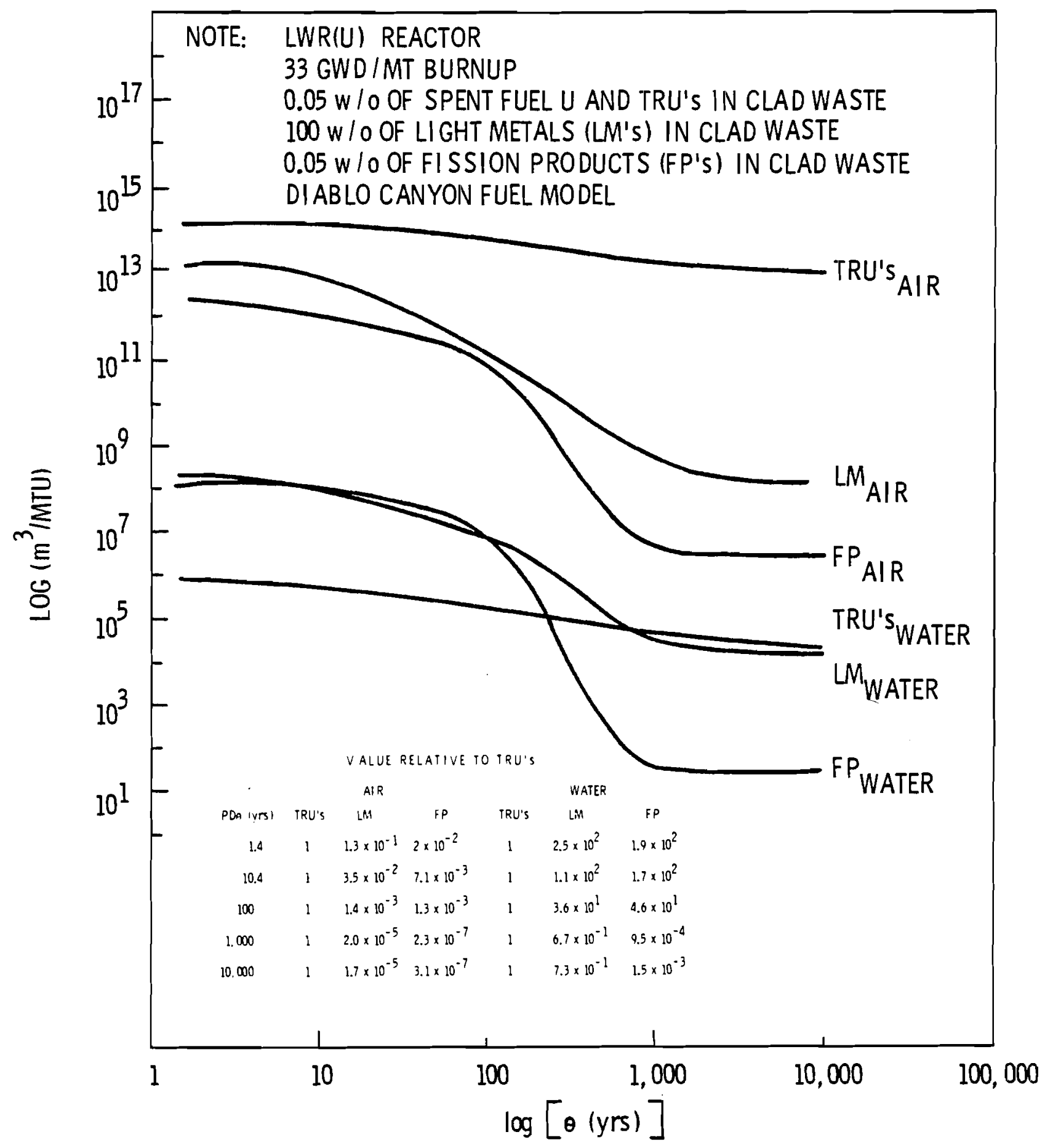

FIGURE 6. Clad Waste Radiological Hazard Index (Air and Water) Versus Post-Reactor Discharge Time 


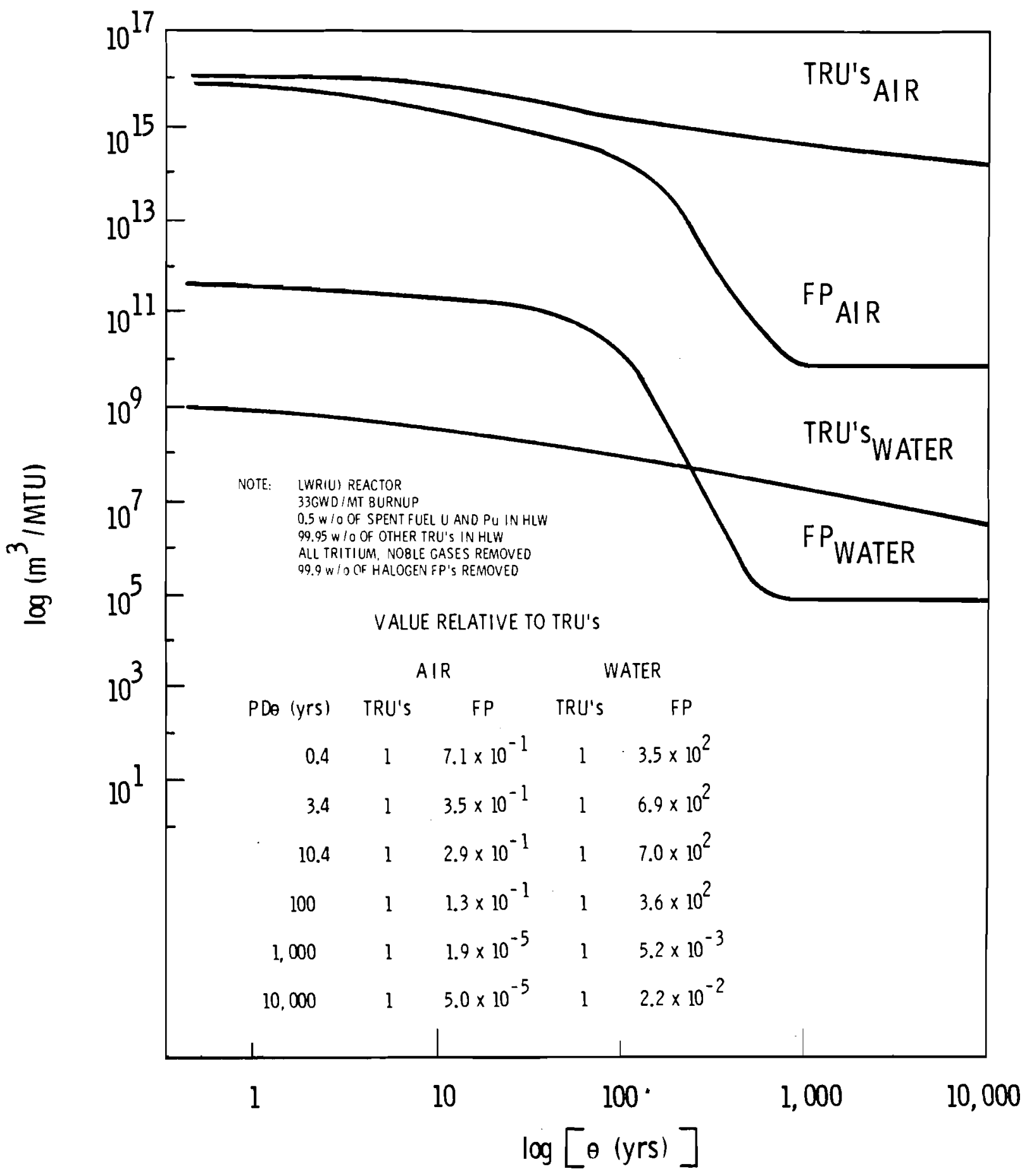

FIGURE 7. HLW Radiological Hazard Index (Air and Water) Versus Post-Reactor Discharge Time 


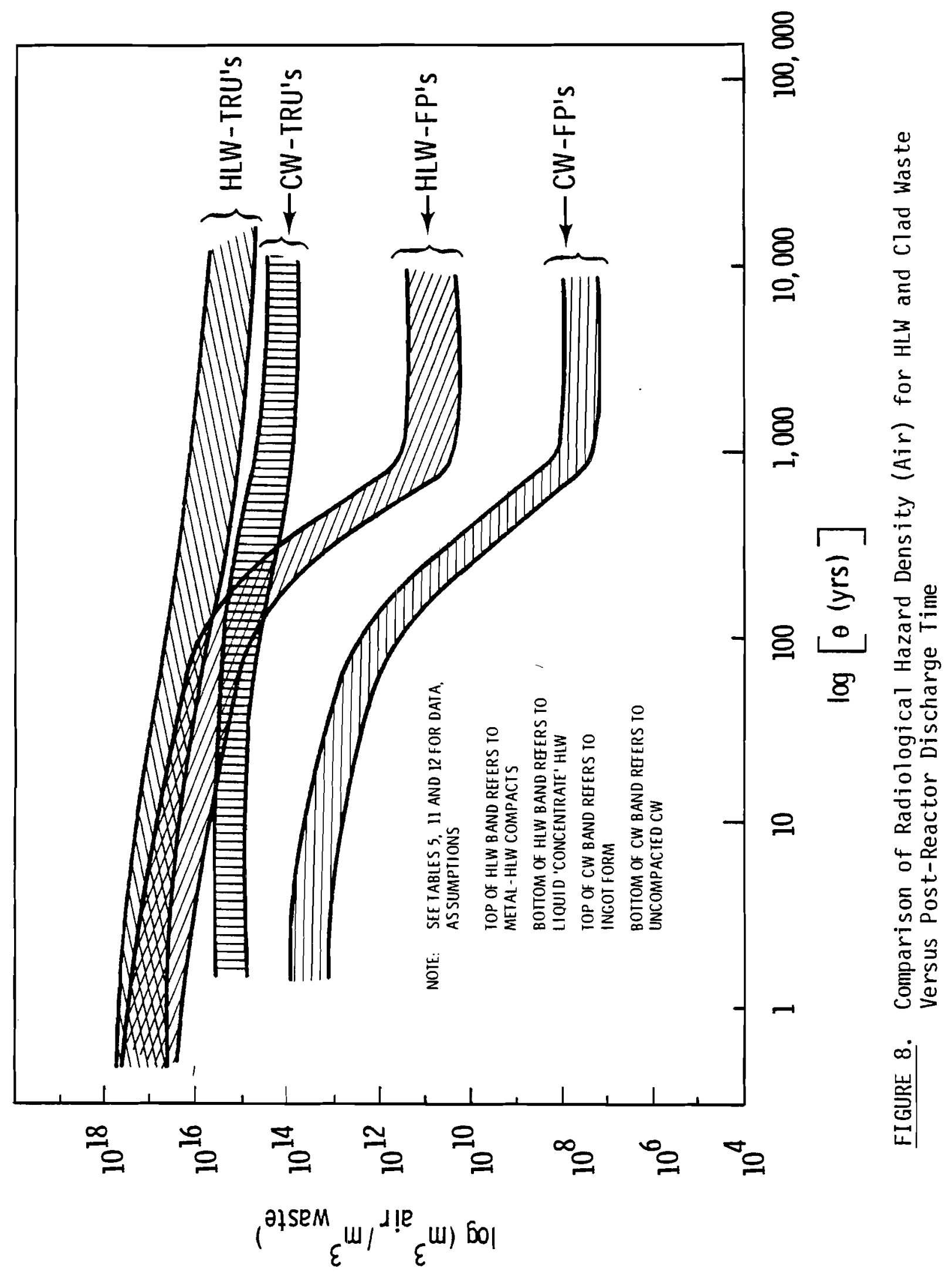




\subsection{THERMAL POWER COMPARISON}

Aggregate thermal power data for the various nuclide classes are given in Table 13 for HLW and clad waste as a function of $\theta$. Data citations are given in the table and contamination assumptions remain the same as for the previous comparisons. Total thermal power is given on both MTU and GWe.yr bases. The total thermal power (GWe.yr basis) is plotted versus $\theta$ in Figure 9 for the $\mathrm{HLW}$ and the clad waste. Using Table 5 data for the various MTU specific volumes for HLW and clad waste, thermal power "densities" were computed for the HLW and the clad waste. These are plotted in Figure 10 versus $\theta$, for the range of densification given in Table 5. On both GWe.yr and $\mathrm{m}^{3}$ bases (Figures 9 and 10, respectively) it is seen that the HLW presents a substantially greater thermal power problem than does the clad waste. Appreciation of the technico-economic significance of the indicated difference would, however, require an analysis similar to that performed by Blomeke and Perona ${ }^{(5)}$ for the interim storage, shipment, and ultimate disposal phases of clad waste management. In the latter study, a computer code was developed for storage and shipment container design, and geologic storage techniques, which is sensitive to both the thermal power and the radiological hazard of the waste. 
TABLE 13. Aggregate Thermal Power According to Nuclide Class for HLW and Clad Waste

\section{Clad Waste (DC Model) ${ }^{(a)}$}

\begin{tabular}{|c|c|c|c|c|c|}
\hline$\theta(y r)$ & $\begin{array}{c}\text { TRU's } \\
\text { (MW/MTU) }\end{array}$ & $\mathrm{FP}^{(\mathrm{c})}$ & $L M^{(d)}$ & $\Sigma M W / M T$ & $\underline{\Sigma M W} / \mathrm{GWe} \cdot \mathrm{yr}$ \\
\hline 0.4 & $4.64-7$ & $9.95-6$ & $6.95-4$ & $7.05-4$ & $2.40-2$ \\
\hline 1.4 & $4.34-7$ & $3.93-6$ & $1.05-4$ & $1.09-4$ & $3.71-3$ \\
\hline 10.4 & $3.95-7$ & $5.10-7$ & $2.71-5$ & $2.80-5$ & $9.53-4$ \\
\hline 100 & $2.11-7$ & $5.25-8$ & $4.26-8$ & $3.06-7$ & $1.04-5$ \\
\hline 1000 & $3.34-8$ & $1.13-11$ & $4.74-11$ & $3.35-8$ & $1.14-6$ \\
\hline 10,000 & $2.30-8$ & $1.04-11$ & - & $2.30-8$ & $7.83-7$ \\
\hline \multicolumn{6}{|c|}{$\underline{H L W}(\mathrm{e})$} \\
\hline 0.4 & $8.05-4$ & $1.99-2$ & & $2.07-2$ & $7.04-1$ \\
\hline 1.4 & $2.44-4$ & $7.85-3$ & & $8.09-3$ & $2.75-1$ \\
\hline 10.4 & $6.99-5$ & $1.02-3$ & & $1.09-3$ & $3.71-2$ \\
\hline 100 & $9.57-6$ & $1.05-4$ & & $1.15-4$ & $3.91-3$ \\
\hline 1000 & $2.10-6$ & $2.25-8$ & & $2.12-6$ & $7.21-5$ \\
\hline 10,000 & $5.20-7$ & $2.08-8$ & & $5.41-7$ & $1.84-5$ \\
\hline 100,000 & $6.48-8$ & $1.34-8$ & & $7.82-8$ & $2.66-6$ \\
\hline
\end{tabular}

a. Diablo Canyon fuel model (see Table 4)

LWR(U) reactor, 33 GWD/MT burnup, 34.03 MTU/GWe.yr

$0.05 \mathrm{w} / \mathrm{O}$ spent fuel $U$ and TRU's in clad waste

$100 \mathrm{w} / 0$ light metals (LM) in clad waste

$0.05 \mathrm{~W} / 0$ fuel fission products (FP's) in clad waste

b. $U$ and TRU's data from Ref. 6 , bringing Pu and $U$ isotopes to spent fuel level

c. FP data from Ref. 6

d. LM data from Ref. 4 (Table 3.29), using table data for short term values; long term data obtained from decay constants calculated from table data

e. $0.5 \mathrm{~W} / 0$ spent fuel $\mathrm{U}$ and $\mathrm{Pu}$ in $\mathrm{HLW}$ $99.95 \mathrm{w} / 0$ of other TRU's in HLW $99.95 \mathrm{~W} / 0$ FP's in HLW 


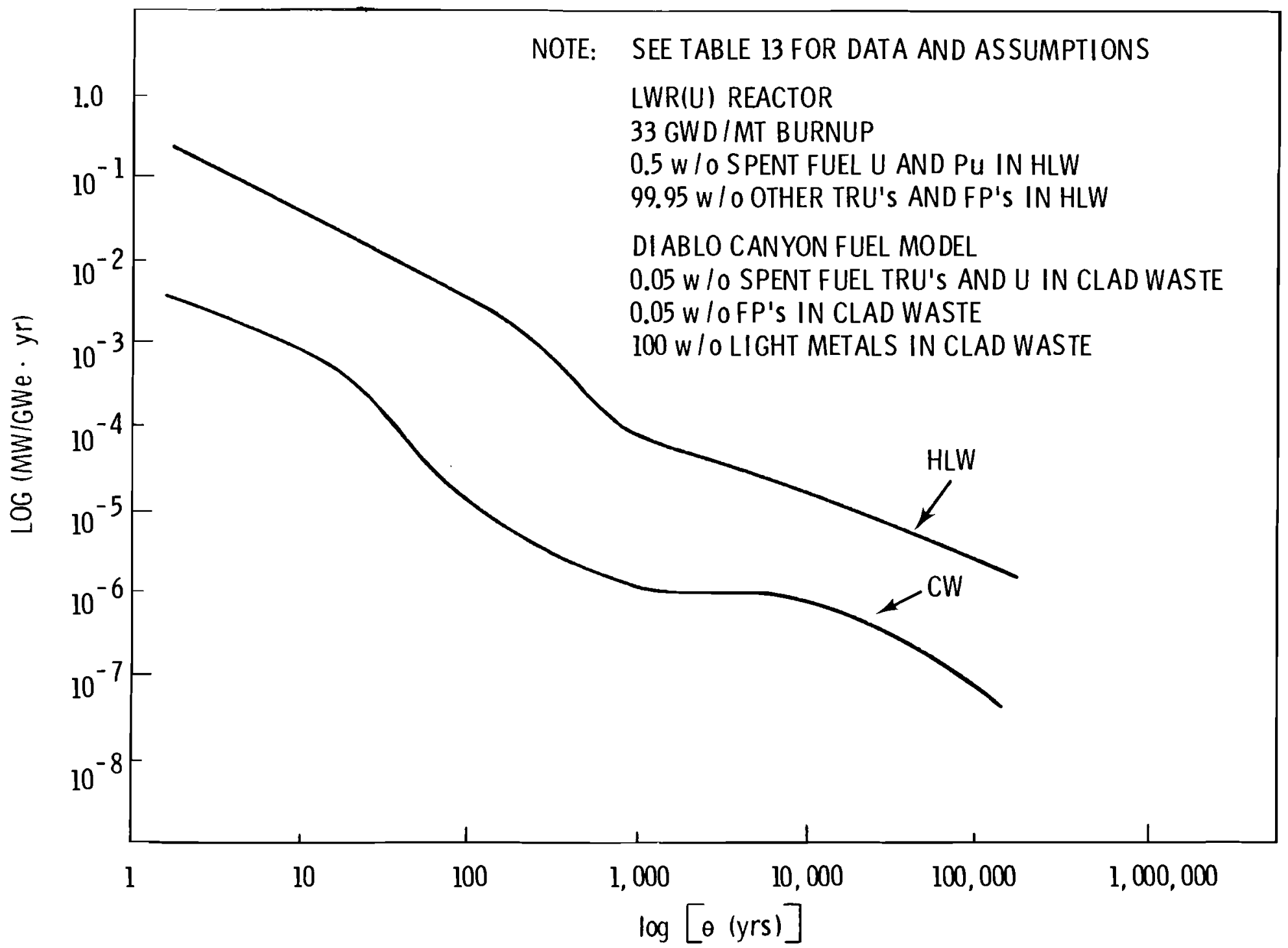

FIGURE 9. Specific Thermal Power (GWe.yr Basis) Burden for HLW and Clad Waste Versus Post-Reactor Discharge Time 


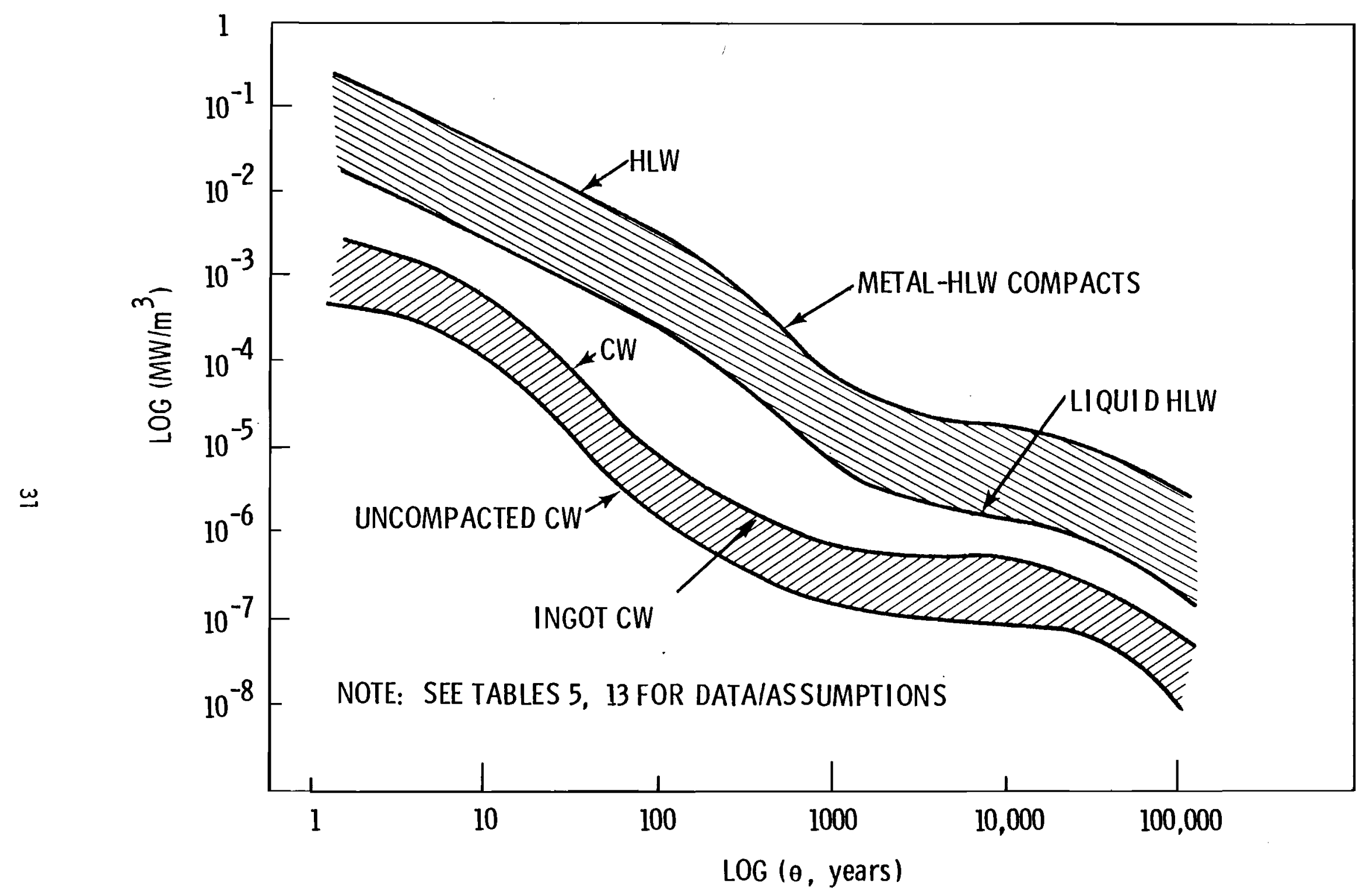

FIGURE 10. Comparison of Aggregate Thermal Power Density for HLW and Clad Waste Versus Post-Reactor Discharge Time 


\subsection{COMPARISON OF RADIOACTIVITY AND THERMAL POWER OF CLAD WASTE FOR REFERENCE FUEL ASSEMBLY AND DIABLO CANYON FUEL MODELS}

The HLW clad waste comparison of this report is primarily based on the LWR(U) reactor at 33 GWD/MT burnup, using the Diablo Canyon Reference Fue 1 Mode1. The Reference Fuel Assembly Model ${ }^{(9)}$ refers to a LWR using a mixed oxide fuel, incorporating first recycle Pu, at a burnup of 25 GWD/MT. It is of interest to gain some measure of the effect of these system differences on the radioactivity and thermal power burdens of the clad waste.

A comparison for the various nuclide classes is given in Table 14 for the RFA and DC fuel models. Absolute values are given for the RFA model, while the $R$ values are the ratios of the $D C$ model value to the RFA model value on both energy (GWe.yr) and volume $\left(m^{3}\right)$ bases. Average $R$ values over the $\theta$ range 1.4 - 10,000 years are also given as a rough measure of comparison for the various nuclide classes. Considering the average $R$ values, as well as the spread in individual values for all nuclide classes, it is evident that the differences between the RFA and $D C$ fuel models are not large and are, in fact, generally within variations which could be effected by reasonable changes in TRU's and fission product contamination assumptions, and clad waste composition assumptions. If this conclusion is valid, then data given in this review for the $D C$ clad waste, for a LWR(U) and 33 GWD/MT system, has a fairly broad range of utility, spanning both uranium and Pu recycle fuels, burnups ranging from 25 to 33 GWD/MT, and clad waste compositions which include most reasonable assumptions in this respect. Furthermore, most technico. economic analyses incorporating the technical characteristics of clad waste given in this review will probably involve uncertainties in economic and public hazard factors which far outweigh the differences in clad waste characteristics noted above. It is suggested that a simple averaging of the technical characteristics of the RFA and the DC fuel models, as a function of $\theta$, would provide clad waste data satisfactory for the purposes of broad scoped economic and public hazard analysis. Considering the nuclear power projections in the WASH-1139 series, ${ }^{(2)}$ the utility of such data should extend well beyond the year 2000 . 
TABLE 13. Comparison of Radioactivity and Thermal Power Burdens of Clad Waste For RFA and DC Fuel Models

\begin{tabular}{|c|c|c|c|c|c|c|c|c|c|c|c|c|c|c|c|c|c|}
\hline \multirow[b]{2}{*}{$\theta(y r s)$} & \multicolumn{6}{|c|}{$\operatorname{IRU}^{\prime} \mathrm{s}(\mathrm{a})$} & \multicolumn{5}{|c|}{$F P^{\prime} s^{(a)}$} & \multicolumn{4}{|c|}{$\operatorname{LM}^{\prime} \mathrm{s}^{(a)}$} & \multirow{2}{*}{\multicolumn{2}{|c|}{$R_{e}^{W} R_{v}^{W}$}} \\
\hline & $\mathrm{Ci} / \mathrm{GWe} \cdot \mathrm{yr}^{\mathrm{t}}$ & W/GWe $\cdot y$ & $R_{e}^{c i}$ & $\mathrm{R}_{\mathrm{v}}^{\mathrm{Ci}}$ & $R_{e}^{W} \quad R$ & $\begin{array}{l}\text { W (c) } \\
v\end{array}$ & $\mathrm{Ci}$ & W & $R_{e}^{c i} R_{v}^{c i}$ & $\mathrm{R}_{\mathrm{e}}^{\mathrm{W}} \mathrm{R}$ & $\begin{array}{l}w \\
v\end{array}$ & $\mathrm{Ci}$ & $W$ & $\mathrm{R}_{\mathrm{e}}^{\mathrm{Ci}}$ & $R_{v}^{c i}$ & & \\
\hline 1.4 & $6.8+3$ & $4.4+1$ & .31 & .48 & .34 & .53 & $4.6+3$ & $2.1+21$ & $6.3)(9.8)$ & .62 & . 97 & $1.6+6$ & $8.6+3$ & .16 & .25 & .42 & .66 \\
\hline 10.4 & $4.3+3$ & $2.2+1$ & .35 & .55 & .59 & .92 & $5.5+3$ & $1.6+1$ & .961 .5 & 1.1 & 1.7 & $1.8+5$ & $1.3+3$ & .45 & .70 & .71 & 1.1 \\
\hline 100 & $3.6+2$ & & .67 & 1.1 & & & $5.9+2$ & & $.98 \quad 1.5$ & & & $5.5+3$ & & 1.7 & 2.6 & & \\
\hline 1000 & $8.2+1$ & & .46 & .72 & & & $4.1-1$ & & $.88 \quad 1.4$ & & & $1.2+2$ & & 1.1 & 1.7 & & \\
\hline 10,000 & $2.0+1$ & & 1.3 & 2.0 & & & $3.8-1$ & & .681 .1 & & & $8.2+1$ & & 1.6 & 2.5 & & \\
\hline & average ' $R$ ' & values: & .62 & .96 & .47 & .73 & & & $.88 \quad 1.4$ & .84 & 1.3 & & & .99 & 1.5 & .57 & .89 \\
\hline
\end{tabular}

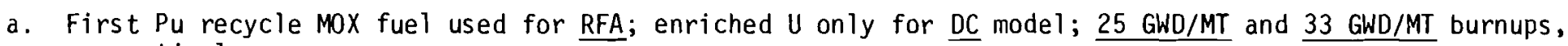
respectively

$0.05 \mathrm{w} / \mathrm{o}$ of spent fuel $U$ and TRU's and FP's assumed to contaminate RFA and DC clad waste; 100\% 1 ight metals (LM's)

see Table 5 for RFA and DC fuel models compositions

b. absolute values refer to RFA model; data from Ref. 9 for RFA model; data from Ref. 3,4,6 for DC model

c. $R=D C$ value/RFA value; $R_{e}$ is ratio on GWe.yr basis; $R_{v}$ is ratio on $\mathrm{m}^{3}$ (clad waste) basis, using die compacted densities for both RFA and DC clad waste (see Table 5); $R_{v}=R_{e} \times 1.56$, where 1.56 is ratio of (GWe.yr/MTHM) $\times\left(M T H M / \mathrm{m}^{3}\right.$ ) product for DC and RFA models, using 32.5 and $32 \%$ overall efficiency, respectively 


\subsection{SOME TECHNICAL MEASURES OF THE WASTE MANAGEMENT PROBLEM OF CLAD WASTE RELATIVE TO HIGH LEVEL WASTE}

Until comprehensive optimization analysis reveals a better measure of the economic/public hazard significance of the various technical indices discussed in this brief review, the simple ratio of these indices for the HLW and clad waste provides a reasonably good and unambiguous measure of the relative importance of these waste streams. Table 15 summarizes these data for the volume, radioactivity, radiological hazard and thermal power indices previously discussed, as a function of $\theta$. The upper part of the table gives these ratios on the basis of the GWe.yr. The lower part gives the comparison on a unit volume $\left(\mathrm{m}^{3}\right)$ basis, for both uncompacted and compacted waste (see table for identification of these waste forms).

The volume comparison is relatively clear and that for the compacted forms is well within current technical competence. Under the compaction assumptions used here, the waste management problem from a volume/GWe.yr standpoint is virtually identical for the HLW and the clad waste. The practical interpretation of the other ratios is much less clear. Under the contamination assumptions used in this comparison, it is evident that the HLW presents more severe radiological and thermal power problems than the clad waste over the entire range of $\theta$. Optimization analysis of the nuclear waste management problem is in progress in this country and abroad. (e.g., 4,5,13) Obviously, simple ratios such as the above will find little use in such analyis, al though the discovery of simple (possibly dimensionless) property groups for the various nuclear waste streams, which can be incorporated in comprehensive economic/public hazard optimization analysis, would be useful indeed. The statement that HLW is "worse than clad waste" from a waste management standpoint is well supported. The quantification of this statement in economic/ public hazard terms appears, however, to pose very substantial analytical problems at this time. 
TABLE 15. Some Technical Measures of Waste Management Problem of Clad Waste Relative to HLW

$$
\left[\begin{array}{l}
\text { Diablo Canyon Fue } 1 \text { Mode } 1 \\
\text { LWR(U) Reactor } \\
33 \text { GWD/MT Burnup }
\end{array}\right]
$$

GWe.yr Basis (ratio CW value to HLW value)

\begin{tabular}{|c|c|c|c|c|c|c|}
\hline \multirow[b]{2}{*}{$\underline{\theta(y r)}$} & \multicolumn{2}{|c|}{ Volume ${ }^{(a)}$} & \multirow{2}{*}{$\underline{R A^{(b)}}$} & \multicolumn{2}{|c|}{ Rad. Hazard $(c)$} & \multirow{2}{*}{$\begin{array}{l}\text { Therma 1 } \\
\text { Power }(d)\end{array}$} \\
\hline & unc. & comp. & & air & water & \\
\hline 1.4 & $6.0-1$ & 1.0 & $5.7-3$ & $8.9-3$ & $1.0-3$ & $1.4-2$ \\
\hline 10.4 & $6.0-1$ & 1.0 & $8.2-3$ & $1.7-2$ & $8.6-4$ & $2.6-2$ \\
\hline 100 & $6.0-1$ & 1.0 & $8.5-2$ & $4.4-2$ & $8.7-4$ & $2.7-3$ \\
\hline 1000 & $6.0-1$ & 1.0 & $5.4-2$ & $4.1-2$ & $4.4-3$ & $1.6-2$ \\
\hline 10,000 & $6.0-1$ & $1.0^{\circ}$ & $1.1-1$ & $8.2-2$ & $1.2-2$ & $4.3-2$ \\
\hline 100,000 & $6.0-1$ & 1.0 & $2.2-1$ & & & $2.9-2$ \\
\hline
\end{tabular}

Unit Vol. Basis (ratio CW value/ $\mathrm{m}^{3}$ to $\mathrm{HLW}$ value $/ \mathrm{m}^{3}$ ) $(\mathrm{e})$

\begin{tabular}{|c|c|c|c|c|c|c|c|c|}
\hline \multirow[b]{3}{*}{$\theta(y r)$} & \multirow{2}{*}{\multicolumn{2}{|c|}{ RA }} & \multicolumn{4}{|c|}{ Radiological Hazard } & \multirow{3}{*}{$\begin{array}{l}\text { Therma } 1 \\
\text { Unc. }\end{array}$} & \multirow{3}{*}{$\begin{array}{l}\text { Power } \\
\text { comp. }\end{array}$} \\
\hline & & & & & & & & \\
\hline & unc. & comp. & unc. & comp. & unc. & comp. & & \\
\hline 1.4 & $8.5-3$ & $5.1-3$ & $1.5-2$ & $8.9-3$ & $1.7-3$ & $1.0-3$ & $2.3-2$ & $1.4-2$ \\
\hline 10.4 & $1.4-2$ & $8.2-3$ & $2.8-2$ & $1.7-2$ & $1.4-3$ & $8.6-4$ & $4 \cdot 3-2$ & $2.6-2$ \\
\hline 100 & $1.4-1$ & $8.5-2$ & $7.3-2$ & $4.4-2$ & $1.5-3$ & $8.7-4$ & $4.5-3$ & $2.7-3$ \\
\hline 1000 & $9.0-2$ & $5.4-2$ & $6.9-2$ & $4.1-2$ & $7.3-3$ & $4.4-3$ & $2.7-2$ & $1.6-2$ \\
\hline 10,000 & $1.8-1$ & $1.1-1$ & $1.4-1$ & $8.2-2$ & $2.0-2$ & $1.2-2$ & $7.2-2$ & $4 \cdot 3-2$ \\
\hline 100,000 & $3.7-1$ & $2.2-1$ & & & & & $4.8-2$ & $2.9-2$ \\
\hline
\end{tabular}

a. uncompacted refers to uncompacted clad waste $\left(0.23 \mathrm{~m}^{3} / \mathrm{MTU}\right)$ and liquid concentrate HLW $\left(0.38 \mathrm{~m}^{3} /\right.$ MTU); compacted refers to die compacted clad waste $\left(0.06 \mathrm{~m}^{3} / \mathrm{MTU}\right)$ and vitrified HLW $\left(0.06 \mathrm{~m}^{3} /\right.$ MTU). See Table 5

b. RA refers to aggregate radioactivity (see Table 7)

c. see Tables 11 and 12 for data and assumptions

d. see Table 13 for data and assumptions

e. unit volume basis $=\mathrm{GWe} \cdot \mathrm{yr}$ basis $x\left[\left(\mathrm{~m}^{3} / \mathrm{GWe} \cdot \mathrm{yr}\right) \mathrm{HLW} /\left(\mathrm{m}^{3} / \mathrm{GWe} \cdot \mathrm{yr}\right) \mathrm{CW}\right]$

$=$ GWe $\cdot y r$ basis $\times 1.67$ for uncompacted waste

$=$ GWe $\cdot y r$ basis $\times 1.00$ for compacted waste 


\subsection{CONCLUSION}

This brief review has attempted some relative characterization of the $\mathrm{HLW}$ and clad waste streams for a nuclear power segment dominated by LWR's. Although the comparison has focused primarily on the LWR(U) reactor at $33 \mathrm{GWD} /$ MT burnup and a specific fuel model (Diablo Canyon Reference Mode1), some data are presented which suggest that the clad waste technical characteristics displayed here may have considerably more general utility in optimization analysis of nuclear waste management up to roughly the year 2000.

The extent to which various actions on clad waste [e.g., decontamination, densification, useful (radioactive) product manufacture] will perturb the overall economic/public hazard situation for nuclear waste management has received some attention $($ e.g., $4,5,8)$ and the relative importance of the clad waste indicated by this review tends to support considerably more work in this regard. The similarity in some of the technical characteristics of the HLW and the clad waste streams suggests the question of whether, or not, some combination of these streams would be expedient and practicable from an overa11 waste management standpoint. Apart from the transmutation concept, ${ }^{(6)}$ at a given post-reactor discharge time the nuclear spent fuel presents a virtually constant array of potentially harmful species for control over geologic time spans. The optimization of the physico.chemical forms for this array, and of the interfaces between these forms and the biosphere, is the essential problem of which the high level waste and the clad waste are principal parts under reasonable contamination assumptions.

This optimization has a number of constraints. Attentive to the paramount public hazard factor, a code of Federal regulations will continue to evolve that will effect a variable influence on waste management strategy. The $10 \mathrm{nCi} / \mathrm{g}$ limit on burial of TRU's contaminated material, and the 10 year limit on the generation-liquid storage-solidification-solid storage-shipment to Federal depository segment of HLW management, are examples. The array of factors common to technico.economic analysis is involved, many of which can only be virtually crude guesses over a long time span. The character and extent of the nuclear power commitment over some multiple of the minimum 
technico-economic planning period are involved. The evolution of technology in treating, transporting and disposing of waste is involved. Probably most important, and most difficult to quantify, is the multitude of factors which determines the general acceptance of nuclear waste management by the public sector.

The prospects for substantial latitude in accomodating to public appraisal of waste management strategies are encouraging. There has been considerable analysis which indicates that the overall cost of nuclear power is not strongly perturbed by a broad scope of measures to minimize the long term public hazard associated with nuclear fuel cycle operations, including reprocessing and waste management. (e.g., 4,6,14) 


\subsection{REFERENCES}

1. R. A. Wolfe, "Problems and Prospects in the Management of Solid Radioactive Waste", J. Environ. Sci., July-August.1975, p. 9.

2. Nuclear Power Growth 1974-2000, WASH-1139(74), February 1974.

3. J. 0. Blomeke, C. W. Kee, J. P. Nichols, "Projections of Radioactive Waste to be Generated by the U.S. Nuclear Power Industry", ORNL-TM-3965, February 1974.

4. Siting of Fuel Reprocessing Plants and Waste Management Facilities, ORNL-4451, July 1970.

5. J. 0. Blomeke, J. J. Perona, "Storage, Shipment and Disposal of Spent Fuel Cladding", ORNL-TM-3650, January 1972.

6. High Leve1 Radioactive Waste Management Alternatives, BNWL-1900, Vo1. 1, May 1974.

7. Code of Federal Regulations, Title 10, Chapter 1, Part 20, Appendix B, Table II, January 1975.

8. N. M. Levitz, B. J. Kullen, M. L. Steindler, "Management of Waste Cladding Hulls. Part 1. Pyrophoricity and Compaction", ANL-8139, February 1975.

9. Alternatives for Managing Wastes from Reactors and Post-Fission Operations in the LWR Fuel Cycle, ERDA-76-43, Vol. 1, Chapter 2, May 1976.

10. Ibid, Vol. 2, Chapter 6.

11. Ibid, Vol. 1, Chapter 3.

12. R. L. Dillon, B. Griggs, R. S. Kemper, R. G. Nelson, "Chemical Decontamination and Melt Densification of Chop-Leach Fuel Hul1s", BNWL-SA-5696, March 22, 1976.

13. H. W. M. Braun, K. Ditterich, J. Schneider, "An Approach to the Optimal Management of Radioactive Wastes in the European Community by Means of Systems Analysis", Proc. Jahrestagung des Facherbandes fur Strahlenschutz, Hel gol and, September 1974.

14. B. C. Finney, R. E. Blanco, R. C. Dahlman, F. G. Kitts, J. P. Witherspoon, "Correlations of Radioactive Waste Treatment Costs and the Environmental Impact of Waste Effluents in the Nuclear Fuel Cycle for Use in Establishing 'As Low as Practicable' Guides--Nuclear Fuel Reprocessing", ORNL-TM-4901, May 1975. 


\section{DISTRIBUTION}

No. of

Copies

OFFSITE

UNITED STATES

A. A. Churm

ERDA Chicago Patent Group

9800 South Cass Avenue

Argonne, IL 60439

S. H. Smiley

Deputy Director for

Fuels and Materials

NRC Directorate of Licensing

for Fuels and Materials

4915 St. Elmo Ave.

Bethesda, MD 20014

R. B. Chitwood

NRC Directorate of Licensing

for Fuels and Materials

Washington, DC 20555

W. P. Bishop

Chief, Waste Management Branch

NRC Division of Materials and

Fuel Cycle Facility Licensing

Washington, DC 20555

W. G. Belter

ERDA Division of Biomedical and

Environmental Research

Earth Sciences Branch

Washington, DC 20545

H. Glauberman

ERDA Uivision of Environmental

Control Technology

:lashington, DC 20545

2 H. Hollister

ERDA Division of Environmenta]

Control Technology

Washington, DC 20545
No. of

Copies

F. P. Baranowski

ERDA Division of Nuclear Fue 1

Cycle and Production

Washington, DC 20545

G. H. Daly

ERDA Division of Nuclear Fue

Cycle and Production

Washington, DC 20545

3 R. W. Ramsey

ERDA Division of Nuclear Fuel

Cycle and Production

Washington, DC 20545

E. E. Sinclair

Assistant Director for Reactor Technology

ERDA Division of Reactor Research and Development

Washington, DC 20545

W. H. McVey

ERDA Division of Nuclear

Fuel Cycle and Production

Washington, DC 20545

G. Wehmann

ERDA Idaho Operations Office

P. 0. Box 2108

Idaho Falls, ID 83401

E. H. Hardison

ERDA Oak Ridge Operations office

P. 0. Box $X$

Oak Ridge, TN 37830

0. T. Turmelle

ERDA Oak Ridge Operations Office P. O. Box $X$

Oak Ridge, TN 37830

E. S. Goldberg

ERDA Savannah River Operations Office

P. 0. Box A

Aiken, SC 29801 
No. of

Copies

206 ERDA Technical Information Center

J. A. Buckham

Allied Chemical Corporation

550 - 2nd Street

Idaho Fal1s, ID 83401

W. Legler

Allied-General Nuclear Services

P. 0. Box 847

Barnwel1, SC 29812

N. M. Levitz

Argonne National Laboratory

9700 South Cass Ave.

Argonne, IL 60439

M. J. Steindler/

L. E. Trevorrow

Argonne National Laboratory

9700 South Cass Ave.

Argonne, IL 60439

E. S. Bartlett

Battelle Memorial Institute

505 King Ave.

Columbus, $\mathrm{OH} 43201$

J. J. Rei11y

Brookhaven National Laboratory

Research Library,

Reference Section

Information Division

Upton, Long Island, NY 11973

R. H. Wiswa 11

Brookhaven National Laboratory

Research Library,

Reference Section

Information Division

Upton, Long Island, NY 11973

Chaim Braun

Brookhaven National Laboratory

Energy Systems Library

Building 902

Upton, NY 11973
No. of

Copies

Mark Goldstein

Brookhaven National Laboratory

Energy Systems Library

Building 902

Upton, NY 11973

Combustion Division

Combustion Engineering, Inc.

Windsor, CT 06095

M. A. Thompson

Rockwe1 1 International

Rocky Flats Division

Golden, CO 80401

C. H. Ice

duPont Company, Aiken (ERDA)

E. I. duPont DeNemours and Co.

Savannah River Laboratory

Aiken, SC 29801

A. S. Jennings

duPont Company, Aiken (ERDA)

E. I. duPont DeNemours and Co.

Savannah River Laboratory

Aiken, SC 29801

L. Henning

Electric Power Research Institute

3412 Hillview Ave.

P. 0. Box 10412

Palo Alto, CA 94304

G. L. Meyer

Environmental Protection Agency

Technology Assessment Div. (AW-559)

Office of Radiation Programs

U. S. Environmental Protection Agency

Washington, DC 20460

B. Mann

Environmental Protection Agency

P. 0. Box 15027

Las Vegas, NV 89114 
No. of

Copies

R. E. Landreth

Environmental Protection Agency

5555 Ridge Ave.

Cincinnati, $\mathrm{OH} 45213$

R. G. Barnes

General Electric Company

175 Curtner Ave.

(M/C 160)

San Jose, CA 95125

L. H. Brooks

Gulf Energy and Environmental Systems

P. 0. Box 81608

San Diego, CA 92138

Central Research Library

Document Reference Section

Oak Ridge National Laboratory (ERDA)

Oak Ridge, TN 37830

Central Research Library, ORNL

Oak Ridge National Laboratory (ERDA)

Oak Ridge, TN 37830

Laboratory Records Dept., ORNL-RC

Oak Ridge National Laboratory (ERDA)

Oak Ridge, TN 37830

C. W. Christenson

Los Alamos Scientific Laboratory (ERDA)

P. 0. Box 1663

Los Alamos, NM 87544

L. J. Johnson

Los Alamos Scientific Laboratory (ERDA)

P. 0. Box 1663

Los Alamos, NM 87544

H. S. Jordan

Los Alamos Scientific Laboratory (ERDA)

P. 0. Box 1663

Los Alamos, NM 87544
No. of

Copies

C. J. Kershner

Monsanto Research Corporation

Mound Laboratory

P. 0. Box 32

Miamisburg, $\mathrm{OH} 45342$

P. Lamberger

Monsanto Research Corporation

Mound Laboratory

P. 0. Box 32

Miamisburg, $\mathrm{OH} 45342$

Stephen Brown

National Lead Company

111 Broadway

New York, NY 10006

John Pomeroy

Technical Secretary

National Academy of Sciences

Committee of Radioactive Waste

Management

National Research Council

2101 Constitution Avenue

Washington, DC 20418

J. P. Duckworth,

Plant Manager

Nuclear Fuel Services, Inc.

P. 0. Box 124

West Valley, NY 14171

E. D. North, Director of

Technical Administration

Nuclear Fuel Services, Inc.

6000 Executive Bivd., Suite 600

Rockville, MD 20852

W. L. Pearl

Nuclear Water and Waste

Technology, Inc.

P. 0. Box 6406

San Jose, CA 95150

Frank von Hippel

Princeton University Center for Environmental Studies, Engineering School

Princeton, NJ 08540 
W. Weart

Sandia Laboratories

Albuquerque, NM 87107

J. Sivinski

Sandia Laboratories

Albuquerque, NM 87107

B. R. Teer

Transnuclear, Inc.

One North Broadway

White Plains, NY 10601

J. O. Blomeke

Union Carbide Corporation (ORNL)

Chemical Technology Division

P. 0. Box $Y$

Oak Ridge, TN 37830

D. E. Ferguson

Union Carbide Corporation (ORNL)

Chemical Technology Division

P. 0. Box $Y$

Oak Ridge, TN 37830

E. H. Kobisk

Union Carbide Corporation (ORNL)

Chemical Technology Division

P. 0. Box $Y$

Oak Ridge, TN 37830

K. H. Lin

Union Carbide Corporation (ORNL)

Chemical Technology Division

P. 0. Box $Y$

Oak Ridge, TN 37830

W. C. McClain

Union Carbide Corporation (ORNL)

Chemical Technology Division

P. 0. Box $Y$

Oak Ridge, TN 37830

W. C. Ulrich

Union Carbide Corporation (ORNL)

Chemical Technology Division

P. 0. Box $Y$

Oak Ridge, TN 37830
Copies

S. E. Logan

University of New Mexico

Albuquerque, NM 87131

R. A. Beall

U.S. Department of Interior

Bureau of Mines

Albany Research Center

1450 W. Queen Avenue

Albany, OR 97321

FOREIGN

Rene Amavis

EURATOM

Health Physics Division

29, Rue Aldringer

Luxembourg, BELGIUM

K. D. B. Johnson

Atomic Energy Research

Establ ishment

Harwe11, Didcot,

Berks, ENGLAND

D. W. Clelland

United Kingdom Atomic Energy Authority

Risley, ENGLAND

R. Bonniaud

Centre de Marcoule

B. P. 106

30 - Bagnols S/Ceze

FRANCE

P. J. Regnaut

Centre d'Etudes Nucleaires

de Fontenay-aux-Roses

Boite Postale 6

92 - Fontenay-aux-Roses

FRANCE

J. Sauteron

Centre d'Etudes Nucleaires de Fontenay-aux-Roses

Boite Postale 6

92 - Fontenay-aux-Roses

FRANCE 
No. of

Copies

Y. J. Sousselier

Centre d'Etudes Nucleaires

de Fontenay-aux-Roses

Boite Postale 6

92 - Fontenay-aux-Roses

FRANCE

Bundesministerium für Forschung und Technologie

Stressemannstrasse 2

5300 Bonn

GERMANY

Hans W. Levi

Hahn-Meitner-Institut

für Kernforschung Berlin (HMI)

Glienicker Strasse 100

1000 Berlin 39

GERMANY

Center for Atomic Energy

Documentation (ZAED)

Attn: Dr. Mrs. Bell

P. 0. Box 3640

7500 Karlsruhe

GERMANY

E. R. Merz

Institut für Chemische

Technologie

KFA-Kernforschungsanlage

Jiil ich GmbH

5170 Jülich

Postfach 1913

GERMANY

K. H. Rattay

Institut für Chemische

Technologie

KFA-Kernforschungsanlage

Jül ich $\mathrm{GmbH}$

5170 Jülich

Postfach 1913

GERMANY
No. of

Copies

W. Heimerl

Institut für Chemische

Technologie

KFA-Kernforschunsanlage

Jülich $\mathrm{GmbH}$

D517 Jülich

Postfach 1913

GERMANY

W. A. Issel

Gesellschaft für

Wiederaufarbeitung

von Kernbrennstoffen mbh (GWK)

7501 Leopoldshafen

Postfach 60

GERMANY

H. Krause

Gesellschaft für Kernforschung (GfK)

Postfach 3640

D7500 Karlsruhe

GERMANY

H. Witte

NUKEM GmbH

6450 Hanau 11

Postfach 110080

GERMANY

Giacomo Calleri

CNEN

Directtore di Programma

Eurex De] CNEN

Saluggia "Vercelli", ITALY

Willy Bocola

CNEN - C.S.N. Casaccia

Laboratorio Rifiuti Radioattivi

Casella Postale 2400

00100 Roma, ITALY

Ferruccio Gera

CNEN - C.S.N. Casaccia

Laboratorio Rifiuti Radioattivi

Casella Postale 2400

00100 Roma, ITALY 
No. of

Copies

N. S. Sunder Rajan

Bhabha Atomic Research Centre Waste Treatment Division

Trombay, Bombay, 400085 INDIA

K. T. Thomas

Bhabha Atomic Research Centre

Waste Treatment Division

Trombay, Bombay, 400085 INDIA

2 R. V. Ama $1 r a j$

C.W.M.F. Project

P.0. Kalpakkan

Chingleput Dist.

Tami 1 Nadu, INDIA

2 International Atomic Energy Agency

Kärtner Ring 11

P.0. Box 590

A-1011, Vienna, AUSTRIA

H. F. Ramdohr

c/o Friedrich Uhde GmbH

Deggingstrasse 10-12

4600 Dortmund

GERMANY

Dr. Peter J. Dyne

Atomic Energy of Canada Ltd. Whiteshel1 Nuclear Research Establishment

Pinawa, Manitoba

CANADA
No. of

Copies

ONSITE

5 ERDA Richland Operations Office

0. J. Elgert

R. B. Goranson

C. R. Palmer

D. J. Squires

F. R. Standerfer

8 Atlantic Richfield Hanford Company

H. Babad

D. R. Gustafson

R. E. I saacson

D. C. Nelson

A. E. Smith/M. J. Szulinski

J. H. Warren

D. D. Wodrich

File Copy

1 Exxon

Richland, WA 99352

S. J. Beard

1 Joint Center for Graduate Study

J. Cooper

3 United Nuclear Industries, Inc.

A. P. Larrick

2 Westinghouse Hanford Company

A. G. Blasewitz

C. R. Cooley 
No. of

Copies

54 Battelle-Northwest

T. W. Ambrose

J. W. Bartlett

R. J. Bashor

C. L. Brown

L. L. Burger

H. C. Burkholder

N. E. Carter

M. O. Cloninger

G. J. Dau

R. L. Dillon

J. R. Eliason

J. W. Finnigan

J. C. Fox

J. J. Fuquay

B. Griggs

K. M. Harmon

J. H. Jarrett

R. S. Kemper

M. R. Kreiter

J. L. McElroy

L. K. Mudge

R. G. Nelson

R. E. Nightingale

D. E. Olesen

J. A. Partridge

A. M. Platt

F. P. Roberts

K. J. Schneider

J. L. Swanson

P. C. Walkup

E. J. Wheelwright (12)

L. D. Willians

W. K. Winegardner

H. H. Van Tuyl

G. E. Zima (3)

Technical Information (5)

Technical Publications (be) 